Ecclesia. Studia z Dziejów Wielkopolski t. 12 (2017)

doi: 10.14746/e.2017.12.6

\author{
LESZEK WILCZYŃSKI \\ Uniwersytet im. Adama Mickiewicza w Poznaniu \\ Wydział Teologiczny
}

\title{
Pobór kleryków do wojska jako forma represji władz komunistycznych wobec Kościoła katolickiego. Alumni-żołnierze archidiecezji poznańskiej
}

Półwiecze po zakończeniu II wojny światowej było jednym z najtrudniejszych okresów w dziejach Kościoła katolickiego w Polsce. Stanął on wobec wielu wyzwań. Jednym z podstawowych zadań była odbudowa struktur organizacyjnych i administracyjnych, zniszczonych przez niemieckiego i radzieckiego okupanta. Utrudnieniem procesu odbudowy administracyjnej była utrata poważnej części przedwojennego terytorium i „przesunięcie” pojałtańskiej Polski na zachód. Kolejnym powojennym zadaniem Kościoła było odtworzenie kadr duszpasterskich, zdziesiątkowanych szczególnie w wyniku eksterminacyjnej polityki Niemców, trwającej w latach 1939-1945. W skali ogólnopolskiej Kościół utracił w trakcie II wojny światowej aż 20\% duchowieństwa, lecz straty te nie były równomierne, w niektórych bowiem prowincjach kościelnych w Polsce sięgnęły one nawet $40 \%{ }^{1}$. W ślad za odbudową struktur kadrowych ważnym wyzwaniem dla polskiego Kościoła było przywrócenie pełnej posługi duszpasterskiej wśród wiernych, co wobec załamania struktur diecezjalnych, dekanalnych i parafialnych było szczególnie utrudnione w pierwszych latach powojennych. Nie bez znaczenia było odzyskanie przedwojennego majątku kościelnego oraz inwentaryzacja poniesionych strat. I $\mathrm{w}$ tej kwestii straty były nierównomierne. W przypadku archidiecezji poznańskiej szkody materialne Kościoła katolickiego były szczególnie dotkliwe, gdyż rozbiórce uległo 16 kościołów, trzy doszczętnie spłonęły, zniszczeniu

1 J. Kłoczowski, L. Müller, J. Skarbek, Zarys dziejów Kościoła katolickiego $w$ Polsce, Kraków 1986, s. 357-358; Ł. Kędzierski, Działalność duszpasterska arcybiskupa Walentego Dymka (1939-1956), [w:] Ksiądz arcybiskup Walenty Dymek metropolita poznański (1888-1956), red. L. Wilczyński, Poznań 2010, s. 71. 
uległo 11 świątyń, zaś 13 innych uległo poważnym uszkodzeniom. Ponadto 204 kościoły wymagały pilnych remontów w wyniku uszkodzeń oraz zaniedbań, jakie powstały w czasie okupacji niemieckiej²

Od samego początku nastania ładu komunistycznego w Polsce Kościół katolicki traktowany był przez reżim jako najgorszy wróg, dużo groźniejszy i bardziej niebezpieczny od słabej opozycji politycznej, którą ostatecznie rozprawiono się w 1948 roku. Czerpiąc z doświadczeń katolików i prawosławnych w Związku Radzieckim, polscy biskupi mogli spodziewać się najgorszego także w Polsce, lecz przez pierwsze powojenne lata komuniści starali się stworzyć fałszywe wrażenie współpracy z Kościołem i poszanowania jego praw. Już jednak w 1945 roku rząd komunistyczny jednostronnie wypowiedział konkordat, co pozbawiło Kościół katolicki w Polsce ochrony prawnej.

Tymczasem Episkopat Polski podjął starania na rzecz odbudowy Kościoła w powojennej Polsce. W 1945 roku przystąpiono od odtwarzania niezwykle dynamicznie rozwijającej się przed wojną prasy katolickiej. Uruchomiono ponownie seminaria duchowne, wspierano rozwój powołań kapłańskich. W Wielkopolsce sprzyjała temu istniejąca przed 1939 roku tradycja niższych seminariów duchownych funkcjonujących w Poznaniu, Gnieźnie, Ostrowie Wielkopolskim, Śremie, Trzemesznie i Wągrowcu ${ }^{3}$. Ponadto w Poznaniu, staraniem biskupa pomocniczego Walentego Dymka, przystąpiono do odbudowy Wyższego Seminarium Duchownego. Dzięki ofiarności diecezjan i ich bezpośredniemu zaangażowaniu udało się odbudować zniszczone zabudowania seminaryjne i 25 listopada 1946 roku zainaugurowano pierwszy powojenny rok akademicki ${ }^{4}$. Odbudowywano także istniejące przed 1939 roku organizacje katolickie, szczególnie robotnicze i młodzieżowe. Ważnym zadaniem było szybkie przywrócenie struktur dobroczynności katolickiej, którą przed wybuchem II wojny światowej realizowały diecezjalne Związki Caritas, kierowane przez władze zwierzchnie w Poznaniu 5 .

Tymczasem polscy komuniści już od 1944 roku zapoczątkowali politykę stopniowego ograniczania swobody Kościoła i jego obecności w sferze życia publicznego, zakazując klauzuli „tak mi dopomóż Bóg” przy składaniu przysiąg państwowych. Wkrótce ustanowiono laicki charakter szkolnictwa, co stanowiło wstęp do usuwania religii ze szkół, następnie ogłoszono dekret o małżeństwach cywilnych ${ }^{6}$. Na prowincji dochodziło do pierwszych przypadków

\footnotetext{
${ }^{2}$ AAN, sygn. 082/034, s. 188, pismo z dnia 19 lutego 1968 roku.

3 A. Weiss, R. Banaszak, Niższe Seminarium Duchowne Archidiecezji Poznańskiej (1949-1960), Poznań 1999, s. 17.

${ }^{4}$ Wielkie dzieło, „Miesięcznik Kościelny Archidiecezji Poznańskiej”, nr 10 (1947), s. 310.

${ }^{5}$ B. Kumor, Historia Kościoła. Czasy współczesne 1914-1992, t. VIII, Lublin 2001, s. 478.

6 J. Krukowski, Represyjność prawa polskiego w zastosowaniu do Kościoła katolickiego w latach 1944-1956, [w:] Aparat ucisku na Lubelszczyźnie w latach 1944-1956 wobec duchowieństwa
} 
aresztowań wśród duchownych, mordów politycznych na księżach ${ }^{7}$ i budowy sieci agenturalnej wśród kapłanów ${ }^{8}$. Były to wciąż nieśmiałe początki represji, jakie na większą skalę miały spaść na Kościół w niedalekiej przyszłości ${ }^{9}$. Na razie jednak władze państwowe uczestniczyły w uroczystościach religijnych, a żeby uśpić czujność biskupów, księży i katolików świeckich, nierzadko delegowały na uroczystości wojskowe poczty sztandarowe.

Od 1946 roku Episkopat Polski przygotowywał się na pogorszenie relacji państwo-Kościół. Obradujący na Jasnej Górze w dniach 22-24 maja 1946 roku biskupi postanowili o centralizacji kontaktów między Kościołem i państwem na szczeblu Episkopatu, chcąc w ten sposób ustrzec rządców diecezjalnych i duchownych parafialnych przez represjami ze strony komunistycznych władz $^{10}$. Definitywna rozprawa z opozycją polityczną w 1947 roku umożliwiła komunistom przystąpienie do konfrontacji z Kościołem. W tym samym roku zakazano działalności katolickich organizacji młodzieżowych, wtłaczając zarazem młodzież do systemu szkolnictwa całkowicie zlaicyzowanego ${ }^{11}$. Zapoczątkowane w 1948 roku piekło propagandowego szaleństwa miało obrzydzić katolickim społecznikom działalność w organizacjach kościelnych. Wielu $\mathrm{z}$ nich z obawy przed represjami zaprzestało aktywności w stowarzyszeniach religijnych ${ }^{12}$. W 1949 roku władze ogłosiły Dekret o ochronie wolności sumienia $i$ wyznania, następnie dekret o zakazie publicznych form kultu religijnego, a także rozpoczęto akcję masowego aresztowania księży ${ }^{13}$. Władze przyspieszyły też działania, zmierzające do dokonania rozłamu wśród duchownych, inicjując ruch „księży patriotów” oraz katolików świeckich, zrzeszonych w kontrowersyjnym ruchu $\mathrm{PAX}^{14}$.

katolickiego, red. Z. Zieliński, Lublin 2000, s. 30-34; B. Kumor, Historia Kościoła, t. VIII, s. 478; Listy pasterskie Episkopatu Polski 1945-1975, Paryż 1975, s. 36.

${ }^{7}$ M. Lasota, Czasy PRL-u i odzyskana wolność 1945-1992, [w:] Dzieje Kościoła w Polsce, red. A. Wiencek, Bielsko-Biała 2008, s. 423.

${ }^{8}$ J. Żaryn, Kościót katolicki w PRL - wybrane zagadnienia, hipotezy, prowokacje, „Pamięć i Sprawiedliwość", nr 1(2005), s. 13.

9 Protokót z plenarnego posiedzenia KC PPR 10 lutego 1946 roku, „Archiwum Ruchu Robotniczego", t. IX, Warszawa 1984, s. 308-309.

${ }^{10}$ A. Dudek, Państwo i Kościót w Polsce 1945-1970, Kraków 1995, s. 9.

${ }^{11}$ Z. Zieliński, Kościót w Polsce 1944-2007, Poznań 2009, s. 52; M. Lasota, Czasy PRL-u i odzyskana wolność, s. 269.

${ }_{12}$ K. Pawlicka, Polityka władz wobec Kościoła katolickiego (grudzień 1970 - październik 1978), Warszawa 2004, s. 21.

13 J. Krukowski, Represyjność prawa polskiego, s. 30-34; A. Dudek, Państwo i Kościót w Polsce, s. 18; M. Lasota, Ulice nie dla wiernych. Procesje pod nadzorem, [w:] Kościół w godzinie próby 1945-1989. Nieznane dokumenty i świadectwa, red. T. Balon-Mroczka, J. Szarek, Kraków 2006, s. 78-79.

${ }^{14}$ Z. Zieliński, Kościót w Polsce 1944-2007, s. 61; A. Albert, Najnowsza historia Polski 1914-1993, t. 2, Warszawa 1995, s. 134-135; P. Raina, Kościót w PRL. Kościót katolicki a państwo w świetle dokumentów 1945-1989, t. I (lata 1945-1959), Poznań 1994, s. 145-146; S. Wyszyński, 
W 1950 roku komuniści dokonali brutalnego uderzenia w dobroczynną agendę Kościoła - Caritas. Po rozpętaniu medialnej nagonki działaczom dobroczynnym postawiono zarzuty zawłaszczania mienia i korupcji, co stanowiło podstawę do upaństwowienia organizacji oraz przejęcia jej majątku. Stanowiło to wstęp do szerszych działań, których celem była całkowita dezintegracja życia organizacji katolików świeckich ${ }^{15}$. Kolejnym działaniem było uchwalenie ustawy o tzw. dobrach martwej ręki, dzięki czemu komuniści pozbawili Kościół majątku ziemskiego. Proces wywłaszczania Kościoła z posiadanych przezeń nieruchomości dobiegł końca dopiero po koniec lat 50. XX wieku. Jednocześnie władze zaczęły podważać prawo Kościoła do zarządzania parafiami ustanowionymi w świątyniach poprotestanckich, przejętych po 1945 roku. Była to oczywista forma szantażu prawnego, stosowanego przez komunistów wobec polskiego Kościoła katolickiego ${ }^{16}$.

Władze z jednej strony metodycznie niszczyły Kościół w Polsce, z drugiej zaś tworzyły złudne przekonanie o dążeniu do porozumienia z hierarchami. Temu celowi miało służyć powołanie Komisji Mieszanej Episkopatu i Rządu oraz wypracowanie w jej łonie ,porozumienia” z Kościołem, ogłoszonego 14 kwietnia 1950 roku $^{17}$. W istocie akt ten pozostał martwą literą prawa, jedyną zaś trwałą spuścizną wypracowanego fałszywego kompromisu z Episkopatem było utworzenie niesławnego Urzędu ds. Wyznań.

Tymczasem w tle walki z Kościołem komuniści likwidowali jego wpływy społeczne, dążąc do maksymalnego ograniczenia oddziaływania Kościoła na wiernych. Już w 1948 roku podjęto starania na rzecz usunięcia religii ze szkół, lecz działania te nabrały szczególnego tempa po 1950 roku, zmuszając Kościół do rozpoczęcia akcji katechizacyjnej w salkach parafialnych i w oderwaniu od dotychczasowej formuły współpracy z systemem szkolnictwa ${ }^{18}$.

Dzieła zebrane 1949-1953, t. I, Warszawa 1991, s. 79-80; J. Żurek, Ruch „,księży patriotów” w województwie katowickim w latach 1949-1956, Warszawa-Katowice 2009, s. 135-146; A. Dudek, G. Pytel, Bolesław Piasecki. Próba biografii politycznej, Londyn 1990, s. 212.

${ }^{15}$ D. Zamiatała, Caritas. Działalność i likwidacja organizacji 1945-1950, Lublin 2000, s. $77-$ -79; B. Kumor, Historia Kościoła, t. VIII, s. 480; E. Wojcieszyk, Wojewódzki Urzad Bezpieczeństwa Publicznego w Poznaniu wobec Caritas Academica w latach 1946-1950, [w:] Zmagania ze spoleczeństwem. Aparat bezpieczeństwa wobec Wielkopolan w latach 1945-1956, red. A. Łuczak, A. Pietrowicz, Poznań 2008, s. 163-171.

${ }^{16}$ S. Wojtkowiak, Dobra martwej ręki w dawnej Polsce i dziś, „Res Humana”, nr 2-3, 2005, s. 30-35; F. Stopniak, Kościót na ziemiach polskich w latach 1848-1978, [w:] Historia Kościoła od 1848 roku do wspótczesności, t. V, red. R. Aubert, Warszawa 1985, s. 599; Okólnik nr 5 Poznańskiej Kurii Metropolitalnej w 1950 roku, 25 września 1950 roku, [w:] Okólniki Kurii Metropolitalnej w Poznaniu 1949-1953, s. 94-95.

17 J. Żurek, Aparat bezpieczeństwa wobec Kościoła katolickiego w Polsce. Wybrane struktury (1944-1953), „Aparat Represji w Polsce Ludowej 1944-1989”, 1/3/2006, s. 99-100.

18 J. Kłoczowski, Dzieje chrześcijaństwa polskiego, Lublin 2007, s. 349; J. Żaryn, Ostatnie wygnanie biskupa Stanisława Adamskiego (1952-1956), „Więź”, nr 4, 1998, s. 164-172; A. Weiss, 
Oprócz tego władze odrzuciły tradycyjne normy społeczne oparte na trwałości rodziny, wychowania dzieci, systemu wartości i pobożności ${ }^{19}$. Systematycznym represjom poddawano księży parafialnych i biskupów (proces biskupa Czesława Kaczmarka, tzw. sprawa katowickiej kurii biskupiej) ${ }^{20}$. Brutalne działania przeciwko Kościołowi skłoniły Episkopat do wystosowania do rządu memorandum z 8 maja 1953 roku, kończącego się słynnym Non possumus! ${ }^{21}$ Konsekwencją nieprzejednanej postawy Kościoła było nieoczekiwane uwięzienie prymasa Stefana Wyszyńskiego (1953-1956).

Wiatr zmian wiejących z Moskwy po śmierci Józefa Stalina przyniósł wszystkim krajom bloku wschodniego destalinizację. Na jej fali do władzy w Warszawie doszedł Władysław Gomułka, z którym społeczeństwo wiązało wielkie nadzieje na liberalizację systemu i powiększenie swobód obywatelskich. W istocie okazał się on partyjnym doktrynerem o niewielkiej umiejętności dostosowania politycznych pryncypiów do realiów życia i oczekiwań

R. Banaszak, Niższe Seminarium Duchowne, s. 25; Okólniki Kurii Metropolitalnej w Poznaniu 1949-1953, s. 290-292; N. Mędlewski, Śp. Ksiądz Arcybiskup Walenty Dymek Metropolita Poznański, „Miesięcznik Kościelny Archidiecezji Poznańskiej” 1957, nr 1/2, s. 12; Ł. Kędzierski, Działalność duszpasterska arcybiskupa Walentego Dymka, s. 71.

${ }^{19}$ B. Kumor, Historia Kościoła, t. VIII, s. 509; W. Dymek, Tydzień Trzeźwości, „Miesięcznik Kościelny Archidiecezji Poznańskiej” 1948, nr 3, s. 81-83; A. Cząstka, Alkohol jako czynnik rozkładowy w rodzinie, „Wiadomości Duszpasterskie” 1950, nr 4/5, s. 98-109; J. Zawadzki, Zagadnienie trzeźwości w Piśmie Świętym, „Wiadomości Duszpasterskie” 1950, nr 8, s. 186-190; J. Szarek, Bezpieka na dróżkach. Kalwaria Zebrzydowska, [w:] Kościól w godzinie próby 1945-1989. Nieznane dokumenty i świadectwa, red. T. Balon-Mroczka, J. Szarek, Kraków 2006, s. 44-46.

20 Metody pracy operacyjnej aparatu bezpieczeństwa wobec Kościołów i zwiazków wyznaniowych 1945-1989, red. A. Dziurok, Warszawa 2004, s. 114-118 (pismo WUBP w Krakowie do Naczelnika Wydziału V MBP z dnia 8 lipca 1949 roku); J. Szarek, Osaczony kapelan. Agentura wokót księdza Władysława Gurgacza, [w:] Kościót w godzinie próby 1945-1989. Nieznane dokumenty $i$ świadectwa, red. T. Balon-Mroczka, J. Szarek, Kraków 2006, s. 20-29; F. Musiał, Śmierć po wyroku. Ksiąd Józef Fudali prześladowany przez UB, [w:] Kościót w godzinie próby 1945-1989. Nieznane dokumenty i świadectwa, red. T. Balon-Mroczka, J. Szarek, Kraków 2006, s. 104-112; J. Żurek, Aparat bezpieczeństwa wobec Kościoła, s. 101; N. Werth, Przemoc przeciwko społeczeństwu. Przemoc, represje i terror w Zwiazku Sowieckim, [w:] Czarna księga komunizmu, thum. K. Wakar i in., Warszawa 2001, s. 235-238; P. Gołdyn, Klika Baziaka i Jałbrzykowskiego. Biskupi powiązani z diecezją lwowską $i$ wileńska w oczach bezpieki, [w:] Kościót w godzinie próby 1945-1989. Nieznane dokumenty i świadectwa, red. T. Balon-Mroczka, J. Szarek, Kraków 2006, s. 202-210; R. Terlecki, Wielki wygnaniec. Metropolita krakowski ksiadz arcybiskup Eugeniusz Baziak, [w:] Kościól w godzinie próby 1945-1989. Nieznane dokumenty $i$ świadectwa, red. T. BalonMroczka, J. Szarek, Kraków 2006, s. 30-43; L. Wilczyński, Ksiadz Arcybiskup Walenty Dymek. Efekty inwigilacji, [w:] Ksiadz arcybiskup Walenty Dymek metropolita poznański (1888-1956), red. L. Wilczyński, Poznań 2010, s. 203-234.

${ }^{21}$ M. Lasota, Czasy PRL-u i odzyskana wolność, s. 432; M. Banaszak, Historia Kościoła katolickiego. Czasy najnowsze 1914-1978, t. IV, Warszawa 1992, s. 75; J. Żaryn, Kościót w Polsce w latach przełomu (1953-1958), Warszawa 2000, s. 19. 
społecznych. Gomułkowska „odwilż” szybko okazała się procesem krótkotrwałym i powierzchownym ${ }^{22}$.

Nie mogąc bagatelizować oczekiwań Kościoła i wiernych, w październiku 1956 roku uwolniono z internowania prymasa Stefana Wyszyńskiego. Wkrótce poluzowano też rygory polityki kościelnej, utworzono Komisję Wspólną, w łonie której wypracowano porozumienie państwa i Kościoła ogłoszone 8 grudnia 1956 roku. Przewidywało ono nowelizację dekretu o obsadzie stanowisk kościelnych, przywrócenie nauczania religii w szkołach oraz możliwość powrotu do Polski wygnanych z niej zakonów ${ }^{23}$. Przyszłość pokazała, że porozumienie nie było przestrzegane przez władze partyjno-państwowe.

Jak już wspomniano, gomułkowska „odwilż” była okresem krótkotrwałym i powierzchownym, lecz na gruncie życia religijnego przyniosła wielką eksplozję pobożności, czego przejawem był wzrost frekwencji wiernych na uroczystościach religijnych. Zaprzestanie szykan wobec świeckich i duchownych sprawiło, że zwiększyła się liczba dzieci uczestniczących w zajęciach religii oraz wzrosła liczba działaczy świeckich w nielicznych organizacjach katolickich. Był to niewątpliwie skutek mniejszej represyjności władzy i jej deklaracji o normalizacji stosunków z Kościołem, ale był to też efekt zarządzonych przez Prymasa Tysiąclecia przygotowań do Millenium Chrztu, zapoczątkowanych w 1956 roku. Zdynamizowanie duszpasterstwa oraz zaprowadzenie nowych form pracy kapłańskiej nieoczekiwanie skłoniło władze partyjno-rządowe do podejrzliwości i wzbudziło obawy przed utratą ,rządu dusz”. Rosła i tak wielka już popularność charyzmatycznego Stefana Wyszyńskiego, malała zaś sympatia wobec „towarzysza Wiesława”, który w ciągu pierwszych dwóch lat sprawowania władzy zawiódł nadzieje Polaków. W 1958 roku stało się jasne, że „odwilż” szybko dobiega końca ${ }^{24}$.

$\mathrm{Na}$ gruncie stosunków państwo-Kościół koniec „odwilży” zapowiadało wsparcie państwa dla hałaśliwych organizacji laickich i ateistycznych. Komisja Wspólna już od końca 1957 roku praktycznie przestała pracować, nabrzmiewały liczne problemy w stosunkach państwo-Kościół. Władze utrudniały prowadzenie katechez i uniemożliwiały ich odbywanie w nowych placówkach szkolnych, szykanom poddawano działaczy świeckich organizacji katolickich, utrudniano powstawanie nowych parafii. Kwestie te zostały podjęte podczas spotkania prymasa Stefana Wyszyńskiego i Władysława Gomułki, ale rozmowy nie przyniosły efektu ${ }^{25}$. Oczywistym aktem wrogości władz

${ }^{22}$ A. Czubiński, Historia Polski XX wieku, Poznań 2000, s. 286.

${ }^{23}$ F. Stopniak, Kościól na ziemiach polskich, s. 601; K. Pawlicka, Polityka władz, s. 26-28; A. Albert, Najnowsza historia Polski, t. 2, s. 349.

${ }^{24}$ D. Jarosz, Polacy a stalinizm, Warszawa 2000, s. 96-98; Z. Zieliński, Kościót w Polsce 1944-2007, s. 141-142.

${ }^{25}$ A. Dudek, Państwo i Kościót w Polsce, s. 60. 
wobec Kościoła była bezprawna rewizja w Instytucie Prymasowskim, dokonana 21 lipca 1958 roku przez funkcjonariuszy milicji i SB. Z początkiem roku szkolnego 1958/1959 zapoczątkowano ,akcję dekrucyfikacyjną”, polegającą na zdejmowaniu krzyży ze ścian w pomieszczeniach szkolnych. $Z$ protestującymi rodzicami brutalnie rozprawiło się ZOMO, przed kolegia trafiło ponad 1000 osób $^{26}$.

Narastający kryzys w stosunkach państwo-Kościół, a później jawna wrogość państwa wobec Kościoła, przełożyła się na nowe formy walki z nim. Znacznie rozszerzono sposoby szykanowania i represjonowania katolików świeckich i duchownych. Działalność bezpieki w tym zakresie „sprofesjonalizowano" w 1963 roku, ustanawiając nowe metody ewidencji kleryków i księży (tzw. Teczka Ewidencji Operacyjnej na Księdza, TEOK) oraz parafii (Teczka Ewidencji Operacyjnej Parafii, TEOP). W aktach tych gromadzono wszelkie informacje dotyczące kandydatów do stanu kapłańskiego, a później wyświęconych duchownych. Podobnie postępowano w przypadku parafii ${ }^{27}$.

Władze zaczęły dążyć do podważenia podstaw wspólnoty kościelnej. Wprawdzie zaprzestano skrytobójczych mordów na duchownych i działaczach świeckich, ale zaprowadzony system szykan administracyjnych utrudniał poprawne funkcjonowanie Kościoła. Władze chciały uzyskać wpływ na kształcenie kleryków, najchętniej zaś uniemożliwiłyby dalszy rozwój stanu kapłańskiego. Dowodziły tego analizy propagandy komunistycznej, która głosiła pogląd, że studia teologiczne i wybór drogi kapłańskiej to „demograficzne marnotrawstwo"28. W 1960 roku władze podjęły starania na rzecz ustanowienia nad seminariami kontroli kuratoriów oświatowych. Wobec oporu Episkopatu rząd zlikwidował niższe seminaria duchowne w Słupsku, Gorzowie, Wolsztynie, Kielcach i Bydgoszczy (1960) ${ }^{29}$, dążąc zarazem do maksymalnego ograniczenia powołań kapłańskich. Pod koniec lat 50. XX wieku wybór drogi kapłaństwa wymagał sporej odwagi, gdyż stawiało to kandydata do seminarium w centrum zainteresowania komunistycznej bezpieki. Na temat kandydata do kapłaństwa zbierano wszelkie dostępne informacje środowiskowe, przepytywano nauczycieli, sąsiadów i znajomych, zapisując je w TEOK. Sam kandydat do seminarium wzywany był na komendy MO, gdzie dokładnie

${ }^{26}$ A. Dziurok, Gomułkowska stabilizacja, [w:] Od niepodległości do niepodległości. Historia Polski 1918-1989, Warszawa 2014, s. 323; J. Żaryn, Kościół w Polsce w latach przełomu, s. 178-182; A. Dudek, Państwo i Kościót w Polsce, s. 77.

${ }^{27}$ Metody pracy operacyjnej, s. 331-335 (Tezy do wykładu nt. „Teczka ewidencji operacyjnej na księdza", 11 czerwca 1963 roku); D. Walusiak, TEOK. Teczka Ewidencji Operacyjnej na Księdza, [w:] Kościól w godzinie próby 1945-1989. Nieznane dokumenty i świadectwa, red. T. Balon-Mroczka, J. Szarek, Kraków 2006, s. 288-296; A. Dziurok, Gomułkowska stabilizacja, s. 325.

${ }^{28}$ B. Kumor, Historia Kościoła, t. VIII, s. 500.

${ }^{29}$ A. Dudek, Państwo i Kościót w Polsce, s. 127-128. 
go przesłuchiwano, strasząc konsekwencjami wyboru drogi życiowej, a jednocześnie nęcąc korzyściami cywilnego życia, które władza mogła „znacznie ułatwić" 30 .

\section{Pobór alumnów do wojska jako forma represji wobec Kościoła}

Wobec nieskuteczności tych metod oraz niepowodzenia inicjatywy objęcia seminariów kontrolą kuratoryjną rząd - nie po raz pierwszy zresztą - złamał porozumienia z 1950 i 1958 roku o zwolnieniu kleryków ze służby wojskowej. W ten sposób władze partyjno-rządowe zamierzały zrealizować kilka zakładanych celów. Pierwszym było powetowanie sobie wizerunkowej porażki, jaką było odstępstwo od objęcia seminariów kontrolą państwową. Kolejnym celem było uderzenie w „reakcyjnych” rządców parafii i biskupów stawiających władzy największy opór ${ }^{31}$. Trzecim celem władzy było poddanie większej presji kleryków i docelowo skłonienie wielu spośród nich do porzucenia drogi do kapłaństwa, a tym samym osłabienie Kościoła katolickiego w Polsce.

Pierwszy pobór alumnów przeprowadzono jeszcze 1955 roku, a zatem przed przełomem 1956 roku. $\mathrm{Z}$ diecezji siedleckiej powołano wówczas do Ludowego Wojska Polskiego (dalej: LWP) 68 alumnów, po dwóch dalszych zaś z diecezji kieleckiej i sandomierskiej. Razem „w kamasze” trafiło 72 kleryków. Jako uzasadnienie podano bezprawne nauczanie religii przez kleryków w okresie wakacyjnym (Siedlce) i zaszczytny charakter służby wojskowej

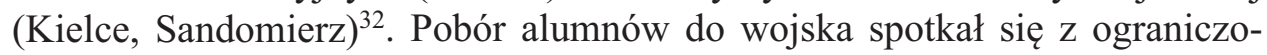
nym oporem ze strony Kościoła i jeszcze mniejszą reakcją zastraszonej opinii publicznej w kraju. Pobór z 1955 roku stanowił więc dla władz komunistycznych próbę sił z Kościołem i probierz reakcji Episkopatu Polski.

Na fali wydarzeń październikowych i późniejszej „odwilży” ekipa Władysława Gomułki zadeklarowała, że nie będzie powoływała do wojska kleryków (1956). Zgodnie z obowiązującym stanem prawnym Urząd ds. Wyznań informował ministra obrony narodowej o personaliach kleryków. Zaświadczenie to obligatoryjnie zaliczało alumna do tzw. ponadkontyngentu, wykluczającego młodego człowieka z obowiązku służby wojskowej.

${ }^{30}$ Metody pracy operacyjnej aparatu, s. 437-438 (notatka funkcjonariusza MO z rozmowy z kandydatem do zakonu paulinów, Tarnowskie Góry, 11 sierpnia 1971 roku).

31 P. Chmielowiec, Niewygodny ordynariusz. Rzeszowska Stużba Bezpieczeństwa wobec ordynariusza przemyskiego biskupa Ignacego Tokarczuka, [w:] Kościót w godzinie próby 1945-1989. Nieznane dokumenty i świadectwa, red. T. Balon-Mroczka, J. Szarek, Kraków 2006, s. 139.

32 A. Setlak, Stużba wojskowa alumnów Wyższych Seminariów Duchownych w PRL i jej ocena $w$ wypowiedziach alumnów i kapłanów rezerwistów. Studium historyczno-socjologiczne na przykładzie Bartoszyc, Olsztyn 2002, s. 17. 
Pogarszanie się stosunków państwo-Kościół, rosnący opór biskupów, konsolidacja wewnętrzna katolików świeckich i bezskuteczność polityki antykościelnej skłoniły władze do silniejszego uderzenia w duchowieństwo. Za cel ponownie obrano alumnów, chcąc w ten sposób uderzyć w rządców diecezji. Wobec braku zgody biskupów na wizytacje kuratoryjne seminariów w Kielcach, Łomży i Olsztynie władze zdecydowały w 1958 roku o przeprowadzeniu w tamtejszych diecezjach poboru alumnów do wojska. Rok później aż 60 alumnów wezwano do wojska z diecezji przemyskiej oraz po trzech z diecezji częstochowskiej i łódzkiej (1959). Szczególnie liczny pobór z diecezji przemyskiej był wynikiem „reakcyjnych” działań tamtejszego biskupa i jego oporu przeciwko poddaniu seminarium kontroli agend państwowych. Odtąd pobór kleryków do wojska stał się niemal rutynowym elementem polityki szykan, stosowanych wobec Episkopatu i Kościoła. Zróżnicowana była tylko skala corocznego poboru, będąca odzwierciedleniem aktualnych stosunków państwo-Kościół.

Wielkiej akcji poboru alumnów do LWP dokonały władze w 1960 roku, co należy wiązać z ogłoszeniem przez Episkopat Polski listu pasterskiego $O a k$ tualnych niebezpieczeństwach, w którym hierarchowie stwierdzili między innymi: „W chwili obecnej wiara Chrystusowa jest zagrożona we wszystkich niemal krajach i w naszym przez ataki ze strony ateizmu, który z miesiąca na miesiąc wzmaga swą działalność i walczy z Kościołem Chrystusowym z nieludzkim wprost fanatyzmem. W tej walce [ateizm] posiada wszystkie nowoczesne środki, a zarazem sam przywdziewa maskę tolerancji, humanitaryzmu i postępu" ${ }^{33}$. Władze komunistyczne uznały te słowa za oczywiste potępienie realizowanej w Polsce polityki i posłużyły się nimi jako pretekstem, dokonując poboru ponad 100 kleryków, najwięcej zaś z diecezji gorzowskiej oraz (ponownie) przemyskiej. W 1961 roku liczba alumnów wezwanych do służby wojskowej spadła, ale rok później wzrosła do 147 (1962). Nie była to największa liczba alumnów jednorazowo wezwanych do służby wojskowej, gdyż od lat 60. XX wieku systematycznie wzrastała liczba kleryków powoływanych do służby w LWP. Działania te należy wiązać z „konkurowaniem” władzy ludowej z Kościołem w zakresie przygotowania do uroczystości Millenium Chrztu/Tysiąclecia Państwa Polskiego.

W roku uroczystości milenijnych (1966) władze dokonały faktycznie największego - jak dotąd - poboru kleryków do wojska (229 osób oraz dalszych 21 alumnów zakonnych), lecz „rekord” ten został pobity w 1968 roku, gdy do wojska wezwano 281 osób. W tym czasie dochodziło do szczególnych napięć między państwem i Kościołem, ale wydaje się, że nie bez znaczenia mogą być też wewnętrzne przetasowania w łonie PZPR, które w 1968 roku doprowa-

\footnotetext{
${ }^{33}$ Listy pasterskie Episkopatu Polski, s. 209-212.
} 
dziły do wydarzeń marcowych. W 1969 roku liczba alumnów powołanych do wojska w skali całego kraju wciąż była wysoka, ale po raz pierwszy wykazywała ona tendencję spadkową.

Łącznie w czasie sprawowania władzy przez Władysława Gomułkę, począwszy od pierwszego poboru w 1958 roku do ostatniego, przeprowadzonego w 1970 roku przed ustąpieniem ,towarzystwa Wiesława”, do służby w LWP wezwano 1913 kleryków oraz dodatkowych 72 w 1955 roku, przed wydarzeniami Października ' $56^{34}$ :

\begin{tabular}{|c|c|c|c|c|c|c|c|c|c|c|c|c|c|c|}
\hline \multirow{2}{*}{ Seminarium } & \multicolumn{14}{|c|}{ Rok } \\
\hline & 1955 & 1958 & 1959 & 1960 & 1961 & 1962 & 1963 & 1964 & 1965 & 1966 & 1967 & 1968 & 1969 & 1970 \\
\hline Białystok & & & & & & & & & 10 & 1 & 7 & 4 & 2 & 4 \\
\hline Częstochowa & & & 3 & & & & & & 9 & 9 & 11 & 10 & 11 & 4 \\
\hline Drohiczyn & & & & 1 & & & & & 3 & 3 & & 1 & 1 & \\
\hline Gdańsk & & & & & & & & & & 7 & 7 & 9 & 5 & 1 \\
\hline Gniezno & & & & 3 & & 8 & 3 & & 9 & 4 & 7 & 9 & 10 & 2 \\
\hline Gorzów & & & & 46 & 27 & & & & 4 & 7 & 7 & & 1 & \\
\hline Katowice & & & & & 6 & 42 & & & 16 & 31 & 32 & 20 & 20 & \\
\hline Kielce & 2 & 41 & & 6 & 6 & & & & & 15 & 9 & 3 & 7 & 2 \\
\hline Kraków & & & & 1 & & 1 & 1 & 2 & 24 & 33 & 34 & 37 & 29 & 18 \\
\hline Lublin & & & & 2 & & & & & & & & & & \\
\hline Łomża & & 48 & & & & & 15 & & & & & 7 & 8 & \\
\hline Łódź & & & 3 & 4 & & & & & 1 & 2 & 4 & 10 & 5 & 7 \\
\hline Olsztyn & & 4 & & & & & 15 & & 4 & 9 & 6 & 6 & 5 & 4 \\
\hline Opole & & & & & & & & 17 & 11 & 9 & 17 & 14 & 9 & 8 \\
\hline Pelplin & & & & & & & & & 7 & 21 & 7 & 16 & 9 & 4 \\
\hline Płock & & & & & & & & & 7 & 5 & & 7 & 19 & 2 \\
\hline Poznań & & & & 2 & & 18 & 15 & 15 & 13 & 8 & 23 & 30 & 12 & \\
\hline Przemyśl & & & 60 & 36 & 7 & 22 & & & 9 & 16 & 7 & 19 & 14 & 17 \\
\hline Sandomierz & 2 & & & & & & & 19 & 7 & 8 & & 16 & 11 & \\
\hline Siedlce & 68 & & & & & & & & & & 8 & 6 & 4 & \\
\hline Tarnów & & & & & & & 62 & 27 & & & 15 & 13 & 29 & \\
\hline
\end{tabular}

${ }^{34}$ A. Setlak, Stużba wojskowa alumnów, s. 20, 25. 


\begin{tabular}{|l|c|c|c|c|c|c|c|c|c|c|c|c|c|c|c|}
\hline \multirow{2}{*}{ Seminarium } & \multicolumn{10}{|c|}{ Rok } & \multicolumn{10}{|c|}{ (1960 } & 1955 & 1958 & 1959 & 1960 & 1961 & 1962 & 1963 & 1964 & 1965 & 1966 & 1967 & 1968 & 1969 & 1970 & \\
\hline Warszawa & & & & 2 & & & 22 & 14 & 8 & 13 & & 12 & 13 & & \\
\hline Włocławek & & & & & & & & & 5 & & & 6 & 4 & & \\
\hline Wrocław & & & & & & 56 & 10 & 8 & 14 & 28 & 24 & 26 & 9 & 7 & suma \\
\hline Razem & 72 & 93 & 66 & 103 & 46 & 147 & 143 & 102 & 161 & 229 & 225 & 281 & 237 & 80 & 1985 \\
\hline
\end{tabular}

Upadek Władysława Gomułki po masakrze robotników na Wybrzeżu w grudniu 1970 roku i objęcie stanowiska I sekretarza KC PZPR przez Edwarda Gierka nie poprawiło istotnie ani ogólnej sytuacji Kościoła, ani też nie zakończyło polityki poboru alumnów do wojska. Wprawdzie nowy premier, Piotr Jaroszewicz, w wystąpieniu telewizyjnym z 23 grudnia 1970 roku zadeklarował wolę ,pełnej normalizacji stosunków między państwem i Kościołem, oczekując zarazem, że wysiłki rządu spotkają się z właściwym zrozumieniem duchownych i świeckich środowisk katolickich" ${ }^{35}$, ale czas pokazał, że były to puste obietnice. Żadne $\mathrm{z}$ istotnych oczekiwań Kościoła nie zostało spełnione, presja wywierana na wiernych i duchownych nie spadła, a stosowane represje stały się co najwyżej bardziej „,subtelne”. Działo się tak mimo woli poszukiwania kompromisu przez Episkopat Polski, a także Stolicę Apostolską. Warto wspomnieć, że antykościelnych działań komunistów polskich w żaden sposób nie powstrzymało nieformalne nawiązanie relacji Polski z Watykanem (1974) ani oficjalna wizyta Edwarda Gierka w Rzymie i spotkanie z Ojcem Świętym $(1977)^{36}$.

W kwestii poboru kleryków do LWP dojście do władzy Edwarda Gierka przyniosło pewne złagodzenie polityki władz (znacznie spadła liczba służących w wojsku alumnów). Kres przymusowej służbie kleryków położył dopiero wybór Karola Wojtyły na Stolicę Piotrową ${ }^{37}$ :

\begin{tabular}{|l|c|c|c|c|c|c|c|c|c|}
\hline \multirow{2}{*}{ Seminarium } & 1971 & 1972 & 1973 & 1974 & 1975 & 1976 & 1977 & 1978 & 1979 \\
\hline Białystok & 2 & & & & & & & 5 & 2 \\
\hline Częstochowa & 3 & 13 & 8 & 3 & 3 & 3 & 7 & 1 & 1 \\
\hline Drohiczyn & 1 & 1 & 1 & & & 2 & & 2 & 4 \\
\hline
\end{tabular}

${ }^{35}$ A. Dudek, Państwo i Kościót w Polsce, s. 231.

${ }^{36}$ M. Lasota, Czasy PRL-u i odzyskana wolność, s. 444; Z. Zieliński, Kościót w Polsce 1944-2007, s. 167; A. Friszke, PRL wobec Kościoła. Akta 1970-1978, Warszawa 2010, s. 33.

${ }^{37}$ A. Setlak, Stużba wojskowa alumnów, s. 25, 28. 


\begin{tabular}{|c|c|c|c|c|c|c|c|c|c|c|}
\hline \multirow{2}{*}{ Seminarium } & \multicolumn{9}{|c|}{ Rok } & \\
\hline & 1971 & 1972 & 1973 & 1974 & 1975 & 1976 & 1977 & 1978 & 1979 & \\
\hline Gdańsk & 3 & 2 & 1 & 2 & & 2 & & 1 & 1 & \\
\hline Gniezno & & 4 & 2 & 4 & 2 & 2 & 2 & 8 & & \\
\hline Gorzów & & 4 & 4 & 15 & 1 & 2 & 6 & 9 & 4 & \\
\hline Katowice & & & 16 & 13 & 5 & 4 & & 22 & & \\
\hline Kielce & 2 & & & 20 & & & & & & \\
\hline Koszalin & & & & 3 & & & & 2 & 4 & \\
\hline Kraków & & 24 & & & & & & & & \\
\hline Łomża & & & 1 & 2 & 2 & 4 & & 2 & 4 & \\
\hline Łódź & 5 & 4 & 6 & 2 & 2 & 1 & & 12 & 2 & \\
\hline Olsztyn & 6 & 2 & 8 & & 6 & & & 5 & 7 & \\
\hline Opole & 3 & 3 & & 21 & & 1 & & & & \\
\hline Pelplin & 3 & 3 & 5 & 10 & 4 & & & 8 & 2 & \\
\hline Płock & & 2 & & 8 & 2 & 3 & & 5 & 4 & \\
\hline Poznań & & & 5 & 13 & 4 & 2 & 9 & 4 & 6 & \\
\hline Przemyśl & 6 & 16 & 13 & 16 & 12 & 1 & 10 & 16 & 6 & \\
\hline Sandomierz & & & 8 & 4 & 4 & 13 & 2 & 1 & 1 & \\
\hline Siedlce & & & 1 & & & 4 & 5 & 3 & 3 & \\
\hline Szczecin & & & & & & 4 & & 3 & & \\
\hline Tarnów & & & 1 & 24 & 5 & 3 & 6 & & & \\
\hline Warszawa & & & 4 & & & & & & 8 & \\
\hline Włocławek & & & 7 & 7 & 7 & & & & 3 & \\
\hline Wrocław & 5 & & 2 & 10 & & 6 & & 7 & 9 & suma \\
\hline Razem & 37 & 78 & 93 & 177 & 59 & 57 & 47 & 111 & 69 & 728 \\
\hline
\end{tabular}

Jak już wspomniano, zarządzając obowiązek służby wojskowej dla alumnów, władze partyjno-rządowe chciały osiągnąć kilka celów. Chodziło o utrudnienie funkcjonowania Kościoła i seminariów w diecezjach zarządzanych przez najbardziej nieugiętych biskupów. Władzy zależało na udowodnieniu biskupom omnipotencji rządzącego Polską reżimu i możliwości jego działania pozaprawnego, gdyż pobór alumnów do wojska był nie tylko niezgodny z tra- 
dycją, sięgającą czasów przedwojennych, ale również niezgodny z porozumieniami wypracowanymi wspólnie z Episkopatem Polski. Zwiększony pobór kleryków z danej diecezji był każdorazową formą „kary” dla rządcy diecezji, przy czym powody poboru z reguły sprowadzały się do trzech przyczyn: negatywnej postawy władz diecezji, wyrażającej się konkretnymi przykładami; utrudniania wizytacji kuratoryjnej w seminariach; niezadowalającej atmosfery wychowawczej w lokalnych Wyższych Seminariach Duchownych ${ }^{38}$.

Poborem i dwuletnią służbą władze zamierzały również oddziaływać na przebywających w wojsku kleryków za pośrednictwem odpowiednio realizowanej polityki „wychowawczej”. Jej zasadniczym celem było odwiedzenie alumna od dalszych studiów teologicznych, a w konsekwencji - porzucenie wybranej drogi kapłaństwa. Nawet jeśli alumn podtrzymał decyzję i po powrocie do seminarium kontynuował studia, a następnie przyjął święcenia, władze dysponowały obszerną wiedzą na jego temat, której w późniejszych latach nie wahały się wykorzystywać.

Badania prowadzone nad służbą wojskową kleryków w LWP dzielą ją na trzy zasadnicze etapy: lata 1959-1964, 1965-1972 i 1973-1980.

\section{Pierwszy etap poboru alumnów do Ludowego Wojska Polskiego (1959-1964)}

Pierwszy okres charakteryzował się słabym przygotowaniem ogniw państwowych, partyjnych, a przede wszystkim wojskowych do obecności alumnów w LWP. Pobór do wojska realizowany w tym czasie miał charakter silnie represyjny wobec konkretnych biskupów, a przez to był nieprzemyślany i realizowany chaotycznie. Przyznawali to zresztą najważniejsi funkcjonariusze partyjni. Alumnów kierowano do wielu jednostek wojskowych na terenie kraju, przez co władze komunistyczne traciły możliwość oddziaływania na nich swoimi metodami „wychowawczymi”. Paradoksalnie poprawiało to sytuację kleryków, gdyż ich obecność w jednostkach wojskowych stawała się dla wielu kolegów-żołnierzy (a nawet ich przełożonych) wydarzeniem dość niecodziennym. Wybór kapłaństwa podnosił prestiż żołnierzy-alumnów w oczach kolegów i dowódców, a dzięki wykształceniu przewyższającemu wykształcenie przeciętnego szeregowca (a nierzadko także podoficera) oraz nienagannej kulturze osobistej cieszyli się oni uznaniem i szacunkiem. Dobry kontakt z inny-

${ }^{38}$ A. Lesiński, Rola kadry wojskowej wobec alumnów-żolnierzy w świetle , Wytycznych generała Wojciecha Jaruzelskiego", [w:] Kompanie kleryckie w Wojsku Polskim 1959-1980. Materiaty $z$ konferencji naukowej zorganizowanej w 5 Pulku Inżynieryjnym w Szczecinie-Podjuchach, 8-9 września 2008, red. J. Kornak, Szczecin 2009, s. 56. 
mi szeregowcami i dowódcami sprzyjał integracji kleryków oraz umożliwiał im oddziaływanie na rówieśników w duchu religijności i pobożności. Dzięki dobremu ogólnemu wykształceniu udzielali oni korepetycji innym żołnierzom, a powodowani uczynnością często zastępowali ich na służbie. Raporty słane przez generała Wojciecha Jaruzelskiego dowodzą, że alumni-żołnierze nierzadko prowadzili zorganizowane akcje chrystianizacyjne wśród szeregowców, a nawet podoficerów przy milczącej zgodzie dowództwa ${ }^{39}$. Oznaczało to, że wcielając kleryków do LWP, władze komunistyczne osiągały efekt odwrotny od zamierzonego: to klerycy stawali się wychowawcami żołnierzy w duchu katolickim, nie zaś laickie wojsko, którego zadaniem było „wybicie z głowy" kapłaństwa alumnom.

W latach 1959-1964 nieprzemyślany był też sposób poboru kleryków i odpowiedzialności „wychowawczej” agend państwa w trakcie ich obecności w LWP. Z ustaleń historyków wiadomo, że procesem indoktrynacji politycznej alumnów-żołnierzy nie zajmował się w pełni odpowiedzialny za to Główny Zarząd Polityczny LWP. Wytyczne w sprawie postępowania oficerów politycznych z żołnierzami-alumnami przygotowywane $\mathrm{w}$ były w IV Departamencie MSW oraz Wydziale Administracyjnym KC PZPR, wobec których Główny Zarząd Polityczny LWP pełnił w zasadzie tylko funkcję służebną ${ }^{40}$.

Cele i oczekiwania postawione przed politycznymi „wychowawcami” w mundurach nie były początkowo sprecyzowane. Represyjny charakter poboru alumnów sprowadzał się do „ubrania w kamasze” i skierowania do ciężkiej służby wojskowej, połączonej z indoktrynacją. Tej jednak alumni poddawali się wyjątkowo opornie, nierzadko stając się powodem lęku u nie dość dobrze wykształconych wojskowych ,politruków”, gdyż w trakcie wychowawczych pogadanek alumni w zaczepny sposób wchodzili w dyskusję z oficerami politycznymi, otwarcie podważając partyjne tezy i dogmaty. Szczególny niepokój budziła polemiczna śmiałość kleryków okazywana publicznie w obecności innych żołnierzy. Już w pierwszej połowie lat 60 . XX wieku władze partyjno-rządowe zaczęły dostrzegać niedomagania prowadzonego dotąd procesu „wychowawczego" alumnów. Wprawdzie partia dysponowała danymi mówiącymi o pełnym powodzeniu procesu ,wychowawczego”, którego skutkiem było odrzucanie powołania przez 1/4 kleryków opuszczających szeregi LWP, ale wydaje się, że dane te - ze względu na przesadny optymizm statystyków

${ }^{39}$ A. Setlak, Stużba wojskowa alumnów, s. 58.

40 T. Krawczak, Ingerencja władz partyjno-rzadowych $w$ formowanie struktur kapłańskich - pobór kleryków do wojska, [w:] Kompanie kleryckie w Wojsku Polskim 1959-1980. Materiaty z konferencji naukowej zorganizowanej w 5 Pułku Inżynieryjnym w Szczecinie Podjuchach, 8-9 września 2008, Szczecin 2009, s. 40. 
partyjnych - uznawano za mało wiarygodne. Dlatego już w 1962 roku Wydział Administracyjny KC PZPR oraz Główny Zarząd Polityczny LWP zauważył konieczność podjęcia pracy „wychowawczej” nad klerykami na podstawie nowych wymagań. Jak przyznawał generał Wojciech Jaruzelski:

Praca polityczno-wychowawcza prowadzona z żołnierzami-alumnami seminariów duchownych musi być nacelowana na zmianę ideologicznej osobowości alumna, a jej wynikiem winna być jego rezygnacja z kontynuowania studiów w seminariach duchownych i przejście na świecki styl życia. Mając na uwadze ten cel, jego ogromną wagę polityczną, pracę $\mathrm{z}$ alumnami należy rozpoczynać już od pierwszej chwili ich pobytu w wojsku i kontynuować przez cały okres ich pobytu w jednostce ${ }^{41}$.

Z poglądem tym zgadzał się Jerzy Sztachelski, który na posiedzeniu Komisji ds. Kleru przy KC PZPR stwierdził, że: „Program wychowawczej pracy winien być podporządkowany głównemu celowi: powiązaniu alumnów z życiem i stopniowej ich laicyzacji. Rezygnacja z powrotu do WSD nie powinna być zasadniczym celem służby wojskowej alumnów, lecz ubocznym produktem stosowanych metod wychowawczych"42.

Służba wojskowa kleryków w pierwszym etapie obecności alumnów w LWP (1959-1964) przyniosła zatem czynnikom partyjno-rządowym sukces raczej umiarkowany. Rozproszenie alumnów w wielu jednostkach wojskowych na terenie całego kraju uniemożliwiało poddanie ich skutecznej indoktrynacji przez wojskowych politruków (w 1964 roku klerycy służyli aż w 94 jednostkach ${ }^{43}$ ). Obecność pojedynczych kleryków w małych jednostkach czyniła ich w pewnym sensie wyjątkowymi, co umacniało $\mathrm{w}$ alumnach poczucie szczególnej roli i utrwalało powołanie kapłańskie. Zasadniczy cel, jaki w początkowym okresie stawiali sobie komuniści - odciągnięcie od kapłaństwa możliwie największej liczby alumnów - również daleki był od realizacji, co niechętnie przyznawali nawet najwyżsi funkcjonariusze partyjni. Najlepszym świadectwem niepowodzenia „branki” kleryków do wojska był rozdźwięk między danymi partyjnymi i kościelnymi w zakresie odstąpienia od kapłaństwa przez alumnów po odbyciu służby wojskowej ${ }^{44}$.

${ }^{41}$ A. Lesiński, Rola kadry wojskowej, s. 63.

${ }^{42}$ T. Krawczak, Ingerencja władz partyjno-rzadowych, s. 47.

43 J. Macholak, Problemy szkolenia wojskowego żolnierzy-alumnów w raportach dowódców do spraw politycznych $w$ latach 1959-1980, [w:] Kompanie kleryckie w Wojsku Polskim 1959-1980. Materiały z konferencji naukowej zorganizowanej w 5 Pułku Inżynieryjnym w Szczecinie Podjuchach, 8-9 września 2008, Szczecin 2009, s. 87.

${ }^{44}$ A. Setlak, Stużba wojskowa alumnów, s. 40; P. Chmielowiec, Niewygodny ordynariusz, s. 139. 


\begin{tabular}{|c|c|c|c|c|c|c|}
\hline \multirow{3}{*}{ Rok } & \multicolumn{3}{|c|}{ Dane z raportu gen. W. Jaruzelskiego } & \multicolumn{3}{|c|}{ Dane kościelne } \\
\hline & \multirow{2}{*}{$\begin{array}{l}\text { Liczba alumnów } \\
\text { zwolnionych } \\
\text { ze służby } \\
\text { wojskowej }\end{array}$} & \multicolumn{2}{|c|}{$\begin{array}{c}\text { Liczba rezygnujących } \\
\text { z seminarium }\end{array}$} & \multirow{2}{*}{$\begin{array}{l}\text { Liczba alumnów } \\
\text { zwolnionych } \\
\text { ze służby } \\
\text { wojskowej }\end{array}$} & \multicolumn{2}{|c|}{$\begin{array}{l}\text { Liczba rezygnujących } \\
\text { z seminarium }\end{array}$} \\
\hline & & Liczba & Procent & & Liczba & Procent \\
\hline 1961 & 63 & 16 & $26,0 \%$ & 63 & 6 & $9,5 \%$ \\
\hline 1962 & 73 & 32 & $44,0 \%$ & 147 & 12 & $8,2 \%$ \\
\hline 1963 & 73 & 21 & $29,0 \%$ & 142 & 10 & $7,0 \%$ \\
\hline 1964 & 150 & 13 & $8,7 \%$ & 160 & 11 & $6,9 \%$ \\
\hline Razem & 359 & 82 & $22,8 \%$ & 512 & 39 & $7,6 \%$ \\
\hline
\end{tabular}

\section{Drugi etap poboru alumnów do LWP (1964-1972)}

Drugi etap poboru kleryków do LWP (1965-1972) władze partyjno-rządowe poprzedziły analizą i podsumowaniem dotychczasowych metod. Protokół z posiedzenia Komisji ds. Kleru przy Wydziale Administracyjnym KC PZPR, przeprowadzonego 29 grudnia 1964 roku, wskazuje na „dojrzewanie” u kierownictwa partyjnego nowej koncepcji oddziaływania na kleryków powołanych do wojska. Przede wszystkim pod wpływem Głównego Zarządu Politycznego LWP postanowiono o kierowaniu kleryków do wybranych jednostek wojskowych i zaprzestaniu akcji rozpraszania alumnów w różnych jednostkach w całej Polsce. Dało to początek specjalnym jednostkom kleryckim w Szczecinie-Podjuchach, Opolu i Gdańsku, przy czym ostatecznie jednostkę z Opola przeniesiono do Brzegu, a gdańską „kompanię klerycką” do Bartoszyc. Wybór tych lokalizacji nie był przypadkowy - umiejscowienie jednostek utrudniało alumnom kontakt z seminariami oraz lokalnym duchowieństwem, niedogodne położenie utrudniało żołnierzom-klerykom wykorzystywanie urlopów i przepustek na dalsze wyjazdy, a kolegom z seminariów oraz przełożonym duchownym przeszkadzało w częstszych wizytach. Członkowie Komisji ds. Kleru wśród innych przyczyn inicjujących pobór alumnów według nowych zasad podawali możliwość specjalistycznego przygotowania kadry politycznej i dowódczej do pracy z klerykami, a jednocześnie odseparowania ich od pozostałych żołnierzy, na których alumni mieli „zły wpływ”. Z perspektywy czasu niepoważnie brzmiały obawy dygnitarzy partyjnych przed „,infiltracją” szeregów wojska przez duchowną „piątą kolumnę”, której obecność w szeregach LWP mogła odkryć przed imperialistycznym wrogiem 
tajemnice Układu Warszawskiego, ale głosy takie pojawiały się podczas obrad wspomnianej komisji ${ }^{45}$.

Skierowanie młodzieży seminaryjnej do specjalistycznych jednostek wojskowych otwierało przed wojskowymi politrukami i propagandystami nowe możliwości. Przede wszystkim do jednostek kleryckich skierowano zupełnie inny typ oficerów. Miejsce dotychczasowych ,klerykałów” w mundurach, którzy skrycie uczestniczyli w życiu religijnym, zajęli zdeklarowani komuniści i antykościelni radykałowie, absolwenci wojskowych kursów religioznawczych i polityczno-partyjnych. Do jednostek kierowano też odpowiednio dobranych poborowych świeckich, wcześniej udzielających się w młodzieżowych organizacjach komunistycznych. Alumnów zamierzano poddawać „nowoczesnym” metodom oddziaływania - poprzez film, wycieczki krajoznawcze i turystyczne, udział $\mathrm{w}$ uroczystościach i imprezach towarzyskich. Celem tych przedsięwzięć było - jak twierdzili partyjni działacze - odkrycie przed klerykami uroków świeckiego życia. Przekonanie takie było całkowicie niedorzeczne, gdyż klerycy doskonale znali to życie, mieli je w nieodległej pamięci i wspomnienia te $\mathrm{w}$ żaden sposób nie wpłynęły na podjęcie decyzji o wyborze kapłaństwa.

Partyjni działacze oczekiwali, że lepiej niż dotąd przygotowani politrucy i dowódcy będą oddziaływali na kleryków bardziej finezyjnie, skłaniając alumnów do porzucenia drogi kapłańskiej. Pomocą służyła partia i Główny Zarząd Polityczny, podejmując systemowe działania na rzecz ułatwienia alumnom porzucenia studiów teologicznych i podjęcia dalszych studiów na dowolnym kierunku i wybranej uczelni, przy jednoczesnym udzieleniu daleko idącego wsparcia finansowego i socjalnego po opuszczeniu seminarium ${ }^{46}$.

Przygotowanie komunistycznego państwa do akcji poboru alumnów w szeregi wojska została w latach 1964-1965 przygotowana programowo dużo lepiej niż wcześniej prowadzone działania. Sukces jednak i tym razem był co najmniej dyskusyjny, o ile nie wątpliwy. W związku z nowym sposobem polityki „wychowawczej”, prowadzonej przez państwo w szeregach wojska, własne metody „opiekuńcze” nad alumnami-żołnierzami zaprowadził Kościół katolicki. Wzmożono kontakt korespondencyjny z klerykami odbywającymi służbę. W obszernej korespondencji informowano ich na bieżąco o życiu w seminarium. Kontakt listowny utrzymywano także z rodzicami kleryków. Wizyty w jednostkach wojskowych składali koledzy z seminarium i ojcowie duchowni, ponadto zdynamizowano duszpasterstwo w parafiach leżących najbliżej ,,jednostek kleryckich”. Odpowiedzią Kościoła na propagandę komunistyczną było regularne wysyłanie alumnom w wojsku prasy katolickiej

${ }^{45}$ T. Krawczak, Ingerencja władz partyjno-rządowych, s. 43-51.

${ }^{46}$ J. Macholak, Problemy szkolenia wojskowego żotnierzy-alumnów, s. 95-107. 
i literatury, a także głoszenie nauk w trakcie odbywania przepustek i urlopów. Przeciwdziałanie ze strony biskupów dostrzegały władze, które domagały się spotęgowania indoktrynacji alumnów ${ }^{47}$.

Postawa kleryków służących w LWP powodowała poczucie bezsilności u politycznych decydentów. Klerycy cierpliwie znosili ciężką pracę fizyczną $\mathrm{w}$ jednostkach ratowniczych, ofiarnie udzielali się też podczas prac polowych i żniwnych w Państwowych Gospodarstwach Rolnych. Z dystansem traktowali nauki polityczne udzielane im przez politruków. Pozostawali obojętni wobec podszeptów o porzuceniu powołania na rzecz wygodnego życia świeckiego, nie robiły też na nich wrażenia częste wizyty funkcjonariuszy SB w domach rodzinnych ${ }^{48}$. Pomimo konsekwentnych szykan, przerywania modlitw, odbierania książeczek do nabożeństwa, krzyżyków i medalików oraz licznych kar za „łamanie” laickiego charakteru LWP, alumni byli żołnierzami zadziwiająco wzorowymi, o czym świadczyły wewnętrzne raporty Ministerstwa Obrony Narodowej:

$\mathrm{Z}$ wcielonych [...] alumnów seminarium duchownego w Kielcach zdecydowana większość to wzorowi żołnierze. Do zajęć przygotowują się sumiennie, udzielają pomocy w nauce żołnierzom słabszym. Ich odpowiedzi na zajęciach politycznych nie budzą zastrzeżeń $[\ldots]$, sami pytań nie zadają, ani też nie biorą aktywnego udziału w dyskusji. Pewne trudności niektórym alumnom sprawia jedynie wychowanie fizyczne. Również dyscyplina alumnów nie budzi zastrzeżeń [...]. Z urlopów i przepustek wracają $\mathrm{w}$ określonym terminie [...]. Typowym dla znacznej części alumnów jest ich małomówność, skrytość, stronienie od żołnierzy niezdyscyplinowanych, wulgarnie wyrażających się, a zbliżają się do żołnierzy inteligentnych i kulturalnych ${ }^{49}$.

\section{Trzeci etap poboru alumnów do LWP (1973-1980)}

Ostatni etap istnienia jednostek kleryckich w szeregach LWP (1973-1980) był czasem schyłkowym tej formy represji i szykan wobec Kościoła. Liczba wcielonych do wojska kleryków była w tym czasie wyraźnie niższa, ale nie należy tego wiązać z deklarowaną przez ekipę Edwarda Gierka „,normalizacją" stosunków państwo-Kościół, ta bowiem - w porównaniu z liczbą i charakterem antykościelnych posunięć władzy - była li tylko pustym frazesem propagandowym. Przeciwko dalszemu utrzymywaniu osobnych jednostek

\footnotetext{
${ }^{47}$ A. Setlak, Stużba wojskowa alumnów, s. 51-64.

${ }^{48}$ Metody pracy operacyjnej, s. 437-438 (notatka funkcjonariusza MO z rozmowy z kandydatem do zakonu paulinów, Tarnowskie Góry, 11 sierpnia 1971 roku).

49 J. Macholak, Problemy szkolenia wojskowego żotnierzy-alumnów, s. 96.
} 
kleryckich przemawiała nie tylko przeciwskuteczność metod „wychowawczych", ale także wysokie koszty utrzymania wspomnianych jednostek (dużo wyższe uposażenie kadry dowódczej, wysokie ogólne koszty administracyjne i techniczne jednostek w Szczecinie-Podjuchach, Brzegu i Bartoszycach). Nie bez znaczenia było też uodpornienie kleryków na polityczne oddziaływanie politruków, do czego młodzież seminaryjna przygotowywana była przez ojców duchowych i alumnów, którzy zakończyli odbywanie służby wojskowej. Kościół potrafił się wykazać elastycznością działania i pomysłowością dużo większą niż nieruchliwe struktury komunistycznego państwa. Przykładem może być zbojkotowanie przez Episkopat Polski obowiązku meldowania słuchaczy w seminariach, w wyniku czego komisje poborowe miały duży kłopot w zlokalizowaniu miejsca pobytu kleryków $(1972)^{50}$.

Kres „eksperymentu” (jak czasem nazywano w partyjnej nowomowie służbę wojskową alumnów) wiązać należy także z szybko zmieniającą się sytuacją polityczną w Polsce w latach 70. XX wieku. Wobec narodzin i rozwoju świeckiej opozycji politycznej w drugiej połowie lat 70. Kościół przestał być głównym wrogiem komunistów. Co więcej, zaczęto go postrzegać jako istotny czynnik stabilizujący sytuację wewnętrzną, a przynajmniej wpływający na tonowanie radykalizmu opozycji. Już w 1973 roku rozwiązano kompanię klerycką w Szczecinie-Podjuchach. Wybór Karola Wojtyły na Stolicę Apostolską 16 października 1978 roku całkowicie zmienił sytuację Kościoła katolickiego w Polsce, przyczyniając się do rozwiązania jednostki kleryckiej w Brzegu rok później (1979), a jednostkę w Bartoszycach zlikwidowano w kwietniu 1980 $\mathrm{roku}^{51}$.

\section{Służba wojskowa kleryków archidiecezji poznańskiej}

Spośród 2713 kleryków, jacy w latach 1955-1980 odbyli służbę w LWP, 179 alumnów pochodziło z poznańskiego seminarium, co stanowi $6,6 \%$ ogólnej liczby żołnierzy-alumnów.

Pierwszy pobór poznańskich kleryków do LWP nastąpił w 1960 roku. Rok później archidiecezję poznańską oszczędzono (1961), lecz w latach 1962-1969 komunistyczne władze dokonywały corocznych poborów wśród alumnów tutejszego seminarium duchownego. W latach 1967-1968 „w kamasze" ubrano największą (jednorazowo) liczbę alumnów: 23 w 1967 roku oraz 30 rok później (1968). W latach 1970-1972 nastąpiła przerwa w przymusowym poborze poznańskich kleryków, ale od następnego roku aż do końca „kleryckiego eks-

\footnotetext{
${ }^{50}$ A. Friszke, PRL wobec Kościoła, s. 47.

${ }^{51}$ K. Pawlicka, Polityka władz, s. 136.
} 
perymentu" władze corocznie powoływały do wojska od kilku do kilkunastu alumnów (1973-1979).

Wspomnienia i świadectwa żołnierzy-alumnów z archidiecezji poznańskiej wskazują, że byli oni poddawani w trakcie swej służby wszelkim stosowanym szykanom i represjom oraz że próbowano ich odciągać od wybranej drogi kapłaństwa. Z drugiej strony zachowana w Archiwum Arcybiskupiego Seminarium Duchownego korespondencja i dokumenty dowodzą wysiłku, jaki władze zwierzchnie archidiecezji oraz koledzy alumnów-żołnierzy wkładali we wspieranie ich, by wytrwali w postanowieniu.

Przed opuszczeniem seminarium i udaniem się w podróż do jednostek wojskowych władze seminaryjne dokonywały uroczystego pożegnania wezwanych do służby kleryków. Nierzadko były to uroczystości kilkudniowe, aby umocnić wśród kleryków wiarę, powołanie kapłańskie i więzy koleżeńskie. W 1964 roku pożegnanie 16 alumnów rozpoczęło się 28 października uroczystym nabożeństwem w poznańskiej Farze. W trakcie nowenny do Matki Boskiej Nieustającej Pomocy ojcowie duchowni seminarium oddali pod opiekę kleryków, a kazanie wygłosił ks. Marian Banaszak. Dzień później, 29 października 1964 roku, w mieszkaniu rektora poznańskiego seminarium, ks. prof. Władysława Pawelczaka, odbyło się kameralne pożegnanie kleryków z udziałem biskupa Tadeusza Ettera:

W czasie wspólnej kawy przemówił Ksiądz Rektor, który zachęcił swych wychowanków do nadprzyrodzonej i mężnej postawy; do naśladowania kapłanów i biskupów, którzy odbyli służbę wojskową, a nawet cierpieli w obozach niemieckich. Wszelkie warunki są dobre, Bóg je daje, należy je tylko wykorzystać. Myśli Księdza Rektora rozwinął Ksiądz Biskup, zachęcając przyszłych wojaków do godnego, kleryckiego i męskiego podjęcia próby w wojsku i do takiej postawy, która zmienia środowisko. Na koniec Ksiądz Biskup udzielił zebranym błogosławieństwa, poświęcił krzyże i wręczył je alumnom, jako zapowiedź zwycięstwa w dniach próby ${ }^{52}$.

Wyjazd alumnów do koszar był początkiem trudnej pracy dla władz poznańskiego seminarium. Należało czym prędzej ustalić adres jednostki wojskowej, do której trafił kleryk. Wprawdzie każdy z nich dostawał powołanie do konkretnej jednostki, ale władze komunistyczne często przenosiły alumnów, aby w ten sposób utrudnić kontakt seminariów z nimi. Odpowiedzią Kościoła na podobne działania ze strony państwa było zintensyfikowanie kontaktów z rodzicami alumnów lub - w przypadku ich śmierci - kręgiem najbliższej

52 Archiwum Arcybiskupiego Seminarium Duchownego w Poznaniu (dalej: AASD), Korespondencja z alumnami w wojsku 1962-1965 (dalej: Korespondencja 1962-1965), Sprawozdanie z pożegnania alumnów odchodzących do wojska (1964), s. 158. 
rodziny. Dzięki temu poznańska kuria i władze seminarium znały miejsce pobytu swego kleryka i mogły na bieżąco utrzymywać z nim kontakt $t^{53}$.

Korespondencja prowadzona przez seminarium z klerykami-żołnierzami była - ku niezadowoleniu władz wojskowych i politycznych - obszerna. Szczególnie zaangażowany w jej prowadzenie był rektor poznańskiego seminarium, ks. prof. Władysław Pawelczak, który osobiście pisał do alumnów. Rektor wykorzystywał każdą okazję, aby wesprzeć swoich podopiecznych. Regularnie wysyłał alumnom życzenia imieninowe, przy tej okazji relacjonując wydarzenia z życia seminaryjnego. W przypadku pobytu kleryka w szpitalu wnikliwie wypytywał o stan zdrowia. Informował też kleryków-żołnierzy o utrzymywaniu kontaktów z ich rodzinami ${ }^{54}$. Wysiłki te miały na celu umocnienie ducha pobożności w klerykach oraz wiary w opiekę i troskę ze strony duchownych przełożonych i kolegów. Listy te stanowiły nierzadko pierwsze i najważniejsze słowa wsparcia udzielone alumnom po przekroczeniu bramy koszar.

Dla wielu alumnów przybycie do jednostek i zetknięcie się z wojskowym rygorem było wydarzeniem wyjątkowo ciężkim. Dotąd byli pilnymi uczniami szkół powszechnych, a później studentami w seminarium i oto nagle stawali w obliczu życia i zwyczajów kompletnie nieznanych. O trudnych początkach służby często wspominali w listach do ojców duchownych z seminarium:

Czuję się dobrze, powoli przystosowuję się do trudnego i twardego życia żołnierskiego. Ostatnio miałem wprawdzie pewne kłopoty ze zdrowiem - minęły one jednak i obecnie biorę już udział we wszystkich zajęciach. Boli mnie jedynie niemożność uczestnictwa we mszy świętej i komunii świętej, brakuje także seminaryjnej atmosfery modlitwy i skupienia. Pocieszam się myślą, że z pomocą Łaski Bożej wytrwam i umocnię [się] w łasce powołania kapłańskiego i wrócę za dwa lata (które przyda się z pewnością w pracy duszpasterskiej) wraz z zapałem do modlitwy 55 .

Paradoksalnie początek służby wojskowej stał się dla kleryków łatwiejszy, gdy obowiązujący do 1964/1965 roku model rozpraszania alumnów w wielu jednostkach wojskowych zastąpiono powoływaniem ich do kompanii kleryckich. Będąc w jednym miejscu, wzajemnie udzielali sobie wsparcia i pomocy, starsi stażem stanowili wsparcie dla nowo powołanych słuchaczy seminariów ${ }^{56}$.

${ }^{53}$ Tamże, s. 1-4, 11, 15.

54 Tamże, Odpis listu rektora Władysława Pawelczaka do alumna Bogdana H. z 23 listopada 1962 roku, s. 17; Odpis listu rektora Władysława Pawelczaka do alumna Bolesława B. z 24 listopada 1962 roku, s. 20.

${ }^{55}$ Tamże, List kleryka Michała M. do ks. rektora Władysława Pawelczaka, Żagań 21 grudnia 1964 roku, s. 183.

${ }^{56}$ AASD, Korespondencja z alumnami w wojsku 1966-1968 (dalej: Korespondencja 1966-1968), List kleryka do ks. rektora Władysława Pawelczaka z dnia 10 listopada 1967 roku, s. 347-349. 
Pierwsze dni i tygodnie służby w koszarach były wyczerpujące. Wprawdzie poczta od rodzin, kolegów i ojców duchownych w seminarium przychodziła na bieżąco, ale liczne codzienne obowiązki uniemożliwiały bieżące odpisywanie na listy. Nierzadko zwłoka wynosiła kilka tygodni. Zmęczenie dawało o sobie znać nawet podczas pisania listów. Klerycy z niecierpliwością oczekiwali złożenia przysięgi, gdyż wiązano z nią nadzieje na nabycie szerszych praw do udziału w praktykach religijnych. Dotychczasowe ograniczenia w swobodzie życia religijnego alumni-żołnierze wiązali z faktem niezłożenia przysięgi wojskowej. Rychło okazywało się, że złożenie przysięgi niewiele zmieniało w stosunku dowództwa do ich potrzeb duchowych. Już w pierwszych tygodniach służby klerycy odkrywali, że najbliższe dwa lata będą dla nich czasem ciężkiej próby, że będą poddawani różnym szykanom i presji ze strony przełożonych. Mimo spełnienia formalnych wymogów do udziału w specjalistycznych kursach szkoleniowych odmawiano klerykom takiego prawa, i to tylko przez wzgląd na ich przynależność do seminariów duchownych. Alumni spotykali się także z odmownym załatwianiem ich wniosków o przeniesienie do innych jednostek, i to mimo oczywistych przesłanek zdrowotnych ${ }^{57}$.

Przypadki opisane powyżej stanowiły dopiero zapowiedź szykan, jakie spadały na kleryków w ciągu kolejnych tygodni i miesięcy służby wojskowej. Bolesnym doświadczeniem dla wszystkich kleryków było „laickie” Boże Narodzenie. Wielu z nich wspominało w korespondencji, że właśnie w czasie poprzedzającym święta zlecano im dużo więcej ciężkich zajęć fizycznych, aby w ten sposób zniechęcić kleryków do wieczornej modlitwy i duchowej pracy nad sobą. Często odmawiano też im przepustki na dni świąteczne, aby w ten sposób uniemożliwić klerykom udanie się do pobliskich parafii, w których gościny udzielali im proboszczowie i wikariuszowie ${ }^{58}$. W 1965 roku w kompanii kleryckiej w Gdańsku wprowadzono w wieczór wigilijny niemal regularny „stan alarmowy":

Święta Bożego Narodzenia przeżywaliśmy w radości i pokoju mimo trudności i przeszkód, którymi starano się nas dręczyć, szczególnie pod względem duchowym. Przez całe święta pilnowano nas prawie na każdym kroku, zwłaszcza w wieczór wigilijny, ponieważ bano się, abyśmy po capstrzyku nie poszli na pasterkę. Zabroniono nam śpiewania kolęd, grożąc nawet karą aresztu. Urządzono nam wprawdzie „kolację żołnierską” w wieczór wigilijny, która miała nam „przypominać" tradycyjną wieczerzę, ale w rezultacie miało to wszystko jakiś obcy

${ }^{57}$ AASD, Korespondencja 1962-1965, List kleryka Stanisława W. do ks. rektora Władysława Pawelczaka z dnia 26 listopada 1962 roku oraz 7 lutego 1963 roku, s. 22, 36.

${ }^{58}$ Tamże, s. 38-39. 
charakter, niereligijny. Czyniono wszystko tak, jak na pewnej odprawie przed świętami zaznaczył dowódca: „zachować tradycję bez jakichś ceremoniałów religijnych"59.

Atmosfera w tej samej jednostce (lecz przeniesionej już do Bartoszyc) była podobna rok później. Zgodnie z rozkazem oficerów politycznych obowiązywał zakaz śpiewania kolęd. Prawo opuszczenia koszar w wieczór wigilijny otrzymali nieliczni, pozostali wzięli udział w ,żołnierskiej kolacji”, podczas której podano zupę owocową i makaron z serem. Klerycy postanowili przerwać tę laicką „uroczystość” przełamaniem się opłatkiem z kolegami i dowódcami, co wprawiło w popłoch część rygorystycznie usposobionych oficerów, inni zaś nie wiedzieli, jak się zachować. Wieczorem dowództwo zarządziło obowiązkową obecność podczas oglądania filmu, a o godz. 22.00 zarządzono capstrzyk. Nie przeszkodziło to jednak klerykom w zorganizowaniu własnych wieczorów wigilijnych, podczas których po cichu śpiewano kolędy i odmawiano modlitwy ${ }^{60}$.

Podobny rodzaj szykan stosowano wobec kleryków w czasie wielkanocnym oraz poprzedzającym inne uroczystości liturgiczne. Najczęściej władze wojskowe albo całkowicie wstrzymywały wydawanie przepustek lub odmawiały ich wydania klerykom, albo też zarządzały „pilne” ćwiczenia poligonowe. Dość często stosowano też wobec alumnów kłamstwo lub podstęp. Przykładem może być historia opisana władzy seminaryjnej przez kleryka Zbigniewa $\mathrm{S}$. Według jego słów prawo udania się do kościoła $\mathrm{w}$ jedną $\mathrm{z}$ niedziel uzyskał dla żołnierzy kapelan wojskowy. Dowództwo rzeczywiście udzieliło określonej grupie szeregowych przepustek, ale nakazało udać się na mecz piłki nożnej oraz do kina. Wszystkim wręczono bilety. Żołnierze skorzystali co prawda z przepustek, ale grupa alumnów i tak udała się do miejscowego kościoła, by wziąć udział w nabożeństwie i spowiedzi ${ }^{61}$.

Brak możliwości uczestnictwa w mszach i drastyczne ograniczenie swobody religijnej były tym rodzajem represji, które klerycy odczuwali najmocniej. Wspominali o tym wszyscy alumni korespondujący z władzami seminaryjnymi w Poznaniu ${ }^{62}$.

Utrzymując kontakt z ojcami duchowymi i księdzem rektorem, klerycy w otwarty sposób pisali o spotykających ich trudnościach. Wymianę listów

${ }^{59}$ AASD, Korespondencja 1966-1968, List kleryka Andrzeja N. do ks. rektora Władysława Pawelczaka z dnia 15 stycznia 1966 roku, s. 212-213.

${ }^{60}$ Tamże, List kleryka Romualda K. do ks. rektora Władysława Pawelczaka z dnia 31 grudnia 1966 roku, s. 287-289.

${ }^{61}$ AASD, Korespondencja 1962-1965, List kleryka Zbigniewa S. do ks. rektora Władysława Pawelczaka z dnia 1 kwietnia 1965 roku, s. 205-206.

62 Tamże, s. 27-28; List kleryka Stanisława M. do ks. rektora Władysława Pawelczaka z dnia 17 listopada 1965 roku, s. 226-227. 
prowadzono w sposób oficjalny, jak również korzystając z życzliwości rodzin, znajomych, duchowieństwa $\mathrm{z}$ miejscowości sąsiadujących z jednostkami i zakonników. Żołnierze-alumni wykorzystywali też przepustki, aby nadać korespondencję pocztą cywilną, przez co istniało mniejsze prawdopodobieństwa, że zostanie ona poddana cenzurze. Alumni mieli pełną świadomość, że korespondencja pisana do nich i przez nich jest poddawana kontroli, z czego zresztą nieraz się śmiali, ale radykalizacja poglądów politruków i części dowódców pod koniec lat 60 . XX wieku sprawiły, że alumni byli dużo bardziej ostrożni i częściej korzystali z pośrednictwa członków rodzin i „kanałów kościelnych” (parafii, klasztorów) przy wysyłce listów ${ }^{63}$.

Jak już wspomniano, utrzymywanie stałej korespondencji pomiędzy seminarium i klerykami w wojsku było istotnym elementem umacniania formacji wewnętrznej alumnów. Sami przyznawali oni w korespondencji, że wiadomości z seminarium były dla nich bardzo ważne. Lektura korespondencji stanowiła „kojącą” odskocznię od mroków koszarowego życia i prymitywnej indoktrynacji, jakiej poddawano ich w trakcie zajęć „oświatowych”. Duży wkład w opiekę nad alumnami odbywającymi służbę wojskową mieli też rodzice i proboszczowie parafii, leżących blisko jednostek wojskowych ${ }^{64}$. O znaczeniu wsparcia, jakiego klerykom-żołnierzom udzielały rodziny i Kościół, doskonale wiedzieli zarówno ojcowie duchowni alumnów, jak również arcybiskup poznański, który zalecał rektorowi utrzymywanie kontaktów z rodzicami alumnów w celu prowadzenia żywej korespondencji ${ }^{65}$.

Należy podkreślić, że arcybiskup sam prowadził korespondencję z klerykami, zawiadamiając ich o wydarzeniach z wewnętrznego życia archidiecezji poznańskiej i Kościoła powszechnego, dziękując za modlitwę ofiarowaną $\mathrm{w}$ jego intencji przez alumnów-żołnierzy. $\mathrm{Z}$ biegiem lat korespondencja między seminarium poznańskim i służącymi w LWP alumnami nabrała charakteru zorganizowanego, co podkreślał w sprawozdaniu dla arcybiskupa rektor ks. Władysław Pawelczak:

Z naszymi wojakami utrzymujemy stały kontakt listowny, przesyłając im kilka razy w roku szkolnym informacje o seminaryjnych aktualiach. Klerycy odbywający służbę wojskową odwzajemniają się nam listami, pisanymi bądź to zbiorowo, bądź indywidualnie. $Z$ okazji urlopów chętnie nawiedzają seminarium. Dwóch kleryków z Bartoszyc otrzymało nawet urlop podczas obchodów milenijnych w Poznaniu, uważając sobie możność uczestnictwa w tych uroczystościach za widoczną łaskę Bożą. Delegacje naszych kleryków odwiedziły swych kolegów

\footnotetext{
${ }^{63}$ AASD, Korespondencja 1966-1968, List z dnia 12 marca 1967 roku, s. 299-300; 309-310.

${ }^{64}$ AASD, Korespondencja 1962-1965, s. 162-169.

${ }^{65}$ Tamże, List abp Antoniego Baraniaka do rektora Władysława Pawelczaka z 3 lutego 1965
} roku, s. 199. 
z okazji składania przysięgi, co sprawiło im wielką radość. Także księża moderatorzy odwiedzili niektóre grupy ${ }^{66}$.

Faktycznie seminarium poznańskie organizowało wyjazdy księży i innych alumnów do kompanii kleryckich, wspierało także wzajemne odwiedzanie się przez alumnów-żołnierzy. Trzeba jednak stwierdzić, że nawet składanie wizyt alumnom było dla władz komunistycznych okazją do szykanowania zarówno żołnierzy-alumnów, jak i ich gości. W 1965 roku grupa kleryków z jednostki w Opolu postanowiła odwiedzić swoich kolegów z Brzegu, ale nie zostali wpuszczeni na teren tamtejszej jednostki pod pretekstem panującej w koszarach epidemii i trwającej właśnie kwarantanny. Rzeczywistą przyczyną było odkrycie faktu, że przyjeżdżający w gościnę szeregowcy to alumni i że chcą odwiedzić kolegów z seminarium ${ }^{67}$.

W październiku 1967 roku, a więc w czasie, gdy władze centralne zwiększały pobór alumnów do wojska, z wizytą do Bartoszyc udał się ks. prof. Jan Pytel wraz z trzema klerykami. Zanim doszło do spotkania z żołnierzami-alumnami duchowny, został zaproszony na rozmowę z zastępcą dowódcy ds. politycznych i kilkoma innymi oficerami. Rozmowa ,przebiegała w atmosferze dobrej i kulturalnej”, chociaż ksiądz profesor poruszył wiele kłopotliwych tematów: szykanowania kleryków, odbierania im książeczek do nabożeństwa i medalików, zmuszania do udziału w kołach zainteresowań i poddawania ich politycznej indoktrynacji. Ksiądz Jan Pytel skrytykował też postawę i zachowanie części oficerów, co jednak nie spotkało się z komentarzem ze strony rozmówców.

Zapewne chcąc zrobić dobre wrażenie, dowództwo jednostki w Bartoszycach zgodziło się na opuszczenie koszar przez 60 alumnów, którzy wraz z ks. prof. Janem Pytlem udali się do pobliskiego klasztoru sióstr serafitek, dokąd przybył także ks. rektor Henryk Gulbinowicz ${ }^{68}$.

Dobra i kulturalna atmosfera, a nawet kurtuazja ze strony wojskowych politruków, o której wspominał ks. prof. Jan Pytel, nie były regułą w kontaktach LWP z opiekunami duchownymi alumnów. Wkrótce po wizycie w Bartoszycach spodziewano się ogłoszenia daty przysięgi wojskowej, na którą zamierzano wydelegować przedstawicieli seminariów. Władze wojskowe postanowiły jednak złośliwie przyspieszyć termin przysięgi o tydzień, przez co klerycy nie mogli na czas wysłać zawiadomienia do rodzin i seminarium w Poznaniu. Szczęśliwym zbiegiem okoliczności ks. Jan Pytel dotarł do Brzegu na czas, gdzie jego - wraz z przedstawicielami innych seminariów - poproszono na

${ }^{66}$ AASD, Korespondencja 1966-1968, Sprawozdanie ks. prof. Władysława Pawelczaka dla abp. Antoniego Baraniaka, 1 lipca 1966 roku, s. 255-256.

${ }^{67}$ AASD, Korespondencja 1962-1965, List z 13 grudnia 1965, s. 230-231.

${ }^{68}$ AASD, Korespondencja 1966-1968, Sprawozdanie ks. Jana Pytla z wizyty w Bartoszycach, 27 listopada 1967 roku, s. 360-362. 
dwugodzinną rozmowę z oficerami politycznymi. Obie strony przedstawiły sobie długą listę zarzutów ${ }^{69}$.

Reakcje wojskowych na wizyty przedstawicieli seminarium poznańskiego w kompaniach kleryckich były bardzo zróżnicowane, co potwierdzał ks. Jan Stanisławski. W styczniu i lutym 1968 roku udał się on do Szczecina oraz Brzegu. O ile w Brzegu spotkanie z klerykami odbyło się bez żadnych problemów, o tyle w Szczecinie przedstawiciele seminarium musieli czekać aż dwie $\operatorname{godziny}^{70}$.

Spotkania z klerykami odbywane podczas wizyt ojców duchownych i kolegów w kompaniach, jak również spotkania $\mathrm{z}$ alumnami-żołnierzami podczas ich urlopów w Poznaniu, dawały władzom kościelnym dużą wiedzę o traktowaniu kleryków w wojsku. Rozmowy te stanowiły istotne uzupełnienie informacji listownych o szykanach i represjach, jakim poddawano alumnów podczas służby w LWP.

Paleta uciążliwości, jakie znosili klerycy w wojsku, była szeroka. Częstym rewizjom poddawano rzeczy osobiste alumnów, byli oni także śledzeni i podsłuchiwani. Spotkanie kilku kleryków w jednym pomieszczeniu było dla dowódców i politruków jednoznaczne ze zorganizowaniem ,podstępnego” zebrania, celem odbycia wspólnej modlitwy. Pomieszczenia, w których przebywali alumni, były ciągle wizytowane, próby modlitwy lub śpiewów religijnych przerywano, organizując jednocześnie alarm w całych jednostkach. Władze wojskowe i wychowawcy polityczni zamierzali w ten sposób skonfliktować żołnierzy-kleryków ze świeckimi szeregowymi.

Książeczki do nabożeństwa oraz wydawnictwa religijne w liczbie ,ponadnormatywnej" często konfiskowano, chociaż stanowczość kleryka i brak jego zgody na odebranie własności potrafiły skutecznie pohamować zapędy nawet najbardziej zapalczywych oficerów politycznych: „Pewnego dnia przybyła do nas specjalna komisja, badająca zainteresowanie żołnierzy. Przeglądając nasze szafki znaleźli u mnie kilka Przewodników Katolickich, Tygodniki Powszechne, Pismo Święte, [podręczniki] historii Kościoła i orzekli, że zakładam bibliotekę parafialną. Zostałem wezwany na specjalną rozmowę, której celem miało być wymuszenie na mnie pozbycia się tych materiałów. Ja jednak powołałem się na pewne ustawy, które nie ograniczają posiadania tych rzeczy w wojsku i dlatego w dalszym ciągu z nich korzystam"71, relacjonował w liście kleryk Wacław K., służący w jednostce pod Sanokiem.

${ }^{69}$ Tamże, Sprawozdanie ks. Jana Pytla z przebiegu składania przysięgi wojskowej w Szczecinie i Brzegu, 16 grudnia 1967 roku, s. 379-380.

70 Tamże, Sprawozdania ks. Jana Stanisławskiego z wizyty w Brzegu oraz Szczecinie-Podjuchach, 28 lutego 1968 roku, s. 401-403.

${ }^{71}$ AASD, Korespondencja 1962-1965, List kleryka Wacława K. do rektora ks. Władysława Pawelczaka z dnia 27 lutego 1964 roku, s. 133-135. 
Z dużo większą bezwzględnością politruków i dowódców spotkali się kilka lat później alumni-żołnierze z kompanii kleryckiej w Brzegu. Jak relacjonował kleryk Florian S. w liście do abp. Antoniego Baraniaka, wkrótce po przyjeździe do jednostki alumnów zapewniono o swobodzie kultu i prawie do posiadania książeczek liturgicznych, lecz: „Przed kilku dniami spotkała nas jawna szykana, a mianowicie musieliśmy oddać wszystkie [posiadane indywidualnie] Pisma Święte, mszaliki, itp., i złożyć to wszystko do plecaków, do których mamy dostęp bardzo rzadki [...]. Po tym incydencie doszedł drugi. Przeprowadzono kontrolę, by wyrwać nam z rąk różaniec święty. Kilku kolegów pozbawiono różańca"72. Rok później klerycy pełniący służbę wojskową w Brzegu sporządzili dla ks. prof. Władysława Pawelczaka listę 27 rodzajów szykan i represji, jakim ich poddawano w trakcie pełnienia służby (autor lub autorzy sprawozdania nie są znani) ${ }^{73}$ :

1. zakaz odbywania modlitwy w postawie klęczącej; w przypadku ,złapania na gorącym uczynku" kleryka karano dodatkową ciężką pracą,

2. zakaz lektury pism religijnych (karana dodatkową ciężką pracą),

3. odbieranie medalików i krzyżyków w brutalny sposób (ze zrywaniem łańcuszków z szyi włącznie),

4. zakaz dostarczania do biblioteczki wojskowej literatury religijnej (dział literatury religijnej stanowiły publikacje o charakterze laickim i antykościelnym),

5. zakaz prywatnego posiadania literatury katolickiej (przypadki niszczenia książek katolickich i profanowania Pisma Świętego przez dowódców w przypadku ich znalezienia w szafkach żołnierzy),

6. ograniczanie czasu wolnego klerykom (celem uniemożliwienia udziału w praktykach religijnych),

7. konfiskowanie podręczników i skryptów seminaryjnych, zakaz nauki przedmiotów teologicznych i dotyczących historii Kościoła,

8. wymuszanie na klerykach udziału w „kółkach zainteresowań” (kółka te były okazją do prowadzenia komunistycznej indoktrynacji); w przypadku konsekwentnej odmowy ze strony kleryków udziału w „kółkach zainteresowań" otrzymywali oni rozkaz karnego udziału w dodatkowych zajęciach i ciężkich pracach polowych,

${ }^{72}$ AASD, Korespondencja 1966-1968, List alumna Floriana S. do abpa Antoniego Baraniaka, 10 listopada 1967 roku, s. 397.

${ }^{73}$ Tamże, Dokument pt. Jednostka wojskowa w Brzegu (Zgorzelcu), s. 450-452 (odręcznie data 28 maja 1968 roku). 
9. złośliwe delegowanie zadań klerykom w niedziele, celem uniemożliwienia praktyk religijnych,

10. wymuszanie na klerykach udziału w konkursach ogólnowojskowych (zasadniczy cel: ograniczenie czasu wolnego alumnów), mimo protestów alumnów-żołnierzy,

11. wymuszanie na klerykach udziału w rocznicowych uroczystościach partyjnych i świętach komunistycznych, straszenie konsekwencjami karnymi (pod pretekstem „wrogości wobec PRL”) w przypadku odmowy,

12. przypisywanie żołnierzom-alumnom udziału w organizacji uroczystości partyjnych i komunistycznych (np. uczczenie V Zjazdu Partii lub 25-lecia LWP),

13. zmuszanie alumnów do udziału w pochodzie pierwszomajowym,

14. dyskryminowanie kleryków przy udzielaniu niedzielnych przepustek lub wydawanie ich warunkowo (po deklaracji, że alumn nie uda się w niedzielę do kościoła),

15. wymuszanie na alumnach deklaracji o wystąpieniu z seminarium duchownego i zarzuceniu drogi kapłaństwa,

16. nakłanianie alumnów do spożywania alkoholu,

17. umyślne i prowokacyjne organizowanie w adwencie i Wielkim Poście hucznych imprez rozrywkowych, zmuszanie do udziału w nich kleryków (pod pretekstem zajęć szkoleniowych),

18. ograniczanie możliwości spotkania z klerykami duchownym gościom (możliwość spotkania się z najwyżej dwoma klerykami),

19. odmawianie gościom-księżom, odwiedzającym kleryków, możliwości spotkania z nimi (pod pretekstem nieobecności lub przeniesienia kleryka do innej jednostki wojskowej),

20. organizowanie prowokacyjnych pogadanek o charakterze antykościelnym i antyreligijnym,

21. łamanie tajemnicy korespondencji („Przesyłki dochodzą niejednokrotnie naruszane"),

22. zmuszanie alumnów do płatnej współpracy z kontrwywiadem wojskowym,

23. utrudnianie klerykom możliwości spotkań z duchownymi (karanie alumnów nawet za przypadkowe spotkanie z księżmi podczas marszu w okolicach koszar),

24. złośliwe organizowanie alarmów i pilnych wymarszów z koszar $\mathrm{w}$ okresie poprzedzającym planowany przyjazd krewnych alumnów lub gości z macierzystego seminarium,

25. odrzucanie próśb o przepustki motywowanych ważnymi przyczynami osobistymi alumna, 
26. uciążliwa agitacja za przynależnością kleryków do Kół Młodzieży Wojskowej (odpowiednik cywilnego Związku Młodzieży Socjalistycznej) oraz Drużyn Służby Socjalistycznej),

27. surowsze od świeckich karanie kleryków za podobne przewinienia.

Sytuacja kleryków w LWP nie uległa istotne poprawie po upadku reżimu Władysława Gomułki. Za czasów jego następcy, Edwarda Gierka (1970-1980), szykany stały się nieznacznie bardziej „,wysublimowane”. Nadal łamano tajemnicę korespondencji, chociaż czyniono to dyskretniej, wykorzystując do tego zdobycze techniki ${ }^{74}$. Nawet pod koniec lat 70 . XX wieku, gdy szczecińską ,kompanię klerycką” już dawno rozwiązano, a wkrótce miano rozwiązać dwie pozostałe kompanie, odbywających w nich służbę alumnów poddawano karom z powodu posiadania literatury religijnej ${ }^{75}$.

Inną uciążliwością dla żołnierzy-kleryków były rutynowe „szkolenia”, prowadzone przez oficerów politycznych. Nierzadko poprzedzały je spotkania $\mathrm{z}$ bezpośrednimi dowódcami już na początku obecności kleryka w jednostce. Spotkania te miały zróżnicowany przebieg i charakter - życzliwy lub pełen wrogości. Postawą wrogą charakteryzowali się wobec kleryków szczególnie podoficerowie, których wykształcenie nie przewyższało szkoły podstawowej ${ }^{76}$. Nisko cenieni przez kleryków byli także politrucy, absolwenci partyjnych kursów i szkoleń, prowadzący zajęcia „wychowawcze” w sposób szablonowy, schematyczny i nudny ${ }^{77}$. Alumni zasadniczo starali się uczestniczyć w tych zajęciach tylko w sposób bierny, nie zabierając głosu, postawienie bowiem słabo wykształconego politruka w kłopotliwej dla niego sytuacji mogło sprowadzić na kleryka uciążliwe konsekwencje. Często zresztą sami oficerowie polityczni starali się pospiesznie wycofać z kłopotliwej dyskusji, w którą - dla swady - wciągali ich co bardziej zaczepni seminarzyści. Zajęcia polityczno-oświatowe były przez alumnów traktowane jako strata czasu, choć zarazem dawały one zmęczonym klerykom możliwość odpoczynku. Wyjątkiem od tej reguły stała się sprawa listu biskupów polskich do biskupów niemieckich z 1965 roku, która zelektryzowała komunistyczną propagandę i sprowokowała ataki na Episkopat i Kościół. Oficerom politycznym zależało szczególnie na poznaniu opinii kleryków w związku z listem, budzącym u znacznej części opinii

${ }^{74}$ AASD, Korespondencja z alumnami w wojsku 1974-1979 (dalej: Korespondencja 1974-1979), List kleryka Andrzeja Sz. z 5 listopada 1977 roku, s. 502.

${ }^{75}$ Tamże, List kleryka Piotra S. z dnia 28 marca 1978 roku.

${ }^{76}$ AASD, Korespondencja 1962-1965, List alumna Zbigniewa B. z 2 grudnia 1964 roku, s. 189$-190$.

77 Tamże, List kleryka Andrzeja S. do rektora Władysława Pawelczaka z dnia 21 stycznia 1966 roku, s. 195-198. 
publicznej liczne kontrowersje ${ }^{78}$. Odpowiedzią biskupów były zalecenia, aby podczas spotkań z żołnierzami-alumnami ojcowie duchowni i koledzy udzielali im wyczerpujących informacji o przyczynach wystosowania historycznego listu do „niemieckich braci w wierze” oraz wysłania do koszar literatury, która precyzyjnie omówiłaby starania Kościoła na rzecz powojennego pojednania i wzajemnego wybaczenia sobie win przez Niemców i Polaków.

Stała presja i liczne szykany wymierzane w kleryków służących w LWP nie przynosiły efektów, jakich spodziewać się mogły czynniki partyjno-rządowe. Alumni dalecy byli od ulegania propagandzie komunistycznej, a do udziału w wojskowych ,kółkach zainteresowan”” podchodzili ze sceptycyzmem. Podkreślić też należy, że ewentualne przystąpienie do takich „,kółek” poprzedzone było konsultacjami kleryków-żołnierzy z przełożonymi w seminarium poznańskim, a nawet rządcą archidiecezji ${ }^{79}$. Poznańscy klerycy uchylali się od udziału w „kółkach zainteresowań”, a jedyny stwierdzony w archiwum Arcybiskupiego Seminarium Duchownego w Poznaniu przypadek wstąpienia dwóch tutejszych alumnów do Drużyny Przodujących Żołnierzy w Brzegu zakończył się - po egzorcie przełożonych - wystąpieniem alumnów z „kółka"80.

Dużo większe pokusy u kleryków poznańskiego seminarium mogły spowodować regularnie składane im przez politruków i dowódców obietnice ułatwienia życia w przypadku porzucenia seminarium i wyboru świeckiej drogi życiowej. W wielu listach kleryków pojawiają się wspomnienia rozmów z oficerami politycznymi składającymi ofertę wyrzeczenia się religii i Kościoła. We wrześniu 1963 roku Główny Zarząd Polityczny LWP podjął szeroko zakrojoną akcję agitacji wśród żołnierzy-kleryków. Jeden z nich, służący we Włodawie, wspominał w liście z 2 września 1963 roku:

W ostatnich dniach sekcja polityczna po raz pierwszy od roku dała znać, że dąży, aby z nas uczynić świeckimi ludzi. Pewnego dnia jeden oficer przyszedł do nas z propozycją: ,jeżeli chcemy zmienić kierunek studiów na świecki możemy to za ich pośrednictwem w bardzo prosty i łatwy sposób uczynić". Przyjęci mamy być bez żadnych egzaminów, obojętnie na jaki kierunek (humanistyczny szczególnie) oraz przez cały okres studiów otrzymywać od państwa pomoc materialną w postaci wysokich stypendiów oraz domów akademickich ${ }^{81}$.

78 AASD, Korespondencja 1962-1965, List z dnia 12 grudnia 1965 roku, s. 228-229; List alumna Stanisława K. do rektora Władysława Pawelczaka z dnia 20 grudnia 1965, s. 227; AASD, Korespondencja 1966-1968, List z dnia 27 lutego 1966 roku, s. 245-246.

${ }^{79}$ AASD, Korespondencja 1962-1965, Szkice korespondencji z 17 maja 1965 roku, s. 211-213.

${ }^{80}$ AASD, Korespondencja 1974-1979, List Pro memoria oraz odpisy listów z 13 i 14 listopada 1978 roku, s. 502, 504-505.

81 AASD, Korespondencja 1962-1965, List kleryka Witolda S. do rektora Władysława Pawelczaka z dnia 2 września 1963 roku, s. 79-81. 
Podobne informacje wysłał w liście datowanym dzień później alumn służący w jednostce wojskowej w Sanoku, relacjonując odbytą wcześniej rozmowę z oficerem politycznym:

Pierwszego września mogę wyjść do cywila z tym jednak, że udam się na dowolnie wybrany kierunek studiów i oczywiście podpiszę, że nie wracam do seminarium. Gwarantują akademik, stypendium państwowe, dostanie się na studia bez egzaminów wstępnych. Krótko mówiąc byt materialny zapewniają. Ja kategorycznie odmówiłem [...]. Liczę się z tym, że tak postawiona sprawa będzie przyczynkiem do dalszych nagabywań. Podobnych rozmów przeprowadzano już ze mną kilka ${ }^{82}$.

Mimo upływu lat stosowane wobec kleryków metody „wychowawcze” nie ulegały istotnym zmianom. W napisanym 29 stycznia 1978 roku liście kleryk odbywający służbę w Brzegu wspominał o masowym wzywaniu alumnów na rozmowy z oficerami politycznymi. Trwały one nierzadko po kilka godzin, w trakcie których próbowano zachęcać kleryków-żołnierzy do porzucenia seminarium. Prośby mieszały się z groźbami. Każdorazowo też żądano zachowania przebiegu rozmowy w tajemnicy ${ }^{83}$.

Podobnie jak ,w cywilu”, także i w szeregach wojska aparat komunistyczny podejmował różne próby rozbijania jedności duchowej księży i kleryków. Miało temu służyć faworyzowanie alumnów rokujących nadzieję na porzucenie kapłaństwa lub przynajmniej pozytywnie ustosunkowanych do niektórych aspektów zmian zachodzących w Polsce. Dlatego tak ważne było zachowanie jedności wśród kleryków pochodzących z archidiecezji poznańskiej. Jeszcze przed wcieleniem do wojska akcent na ducha solidarności kładli ojcowie duchowni w seminarium, pisał o tym także arcybiskup poznański w listach kierowanych do seminarzystów odbywających służbę wojskową.

Duch jedności był cechą charakteryzującą alumnów poznańskich służących w LWP. Solidarność regionalna „poznaniaków” nawet im samym rzucała się w oczy:

Jesteśmy tutaj we czterech. Jeżeli jest czas wolny, to jesteśmy zawsze razem. Inni klerycy tak ze sobą nie sprzyjają. To, że ciągle jesteśmy razem i że razem wykonujemy to co trzeba, jest naszą siłą, bo nie jesteśmy rozbici od wewnątrz. Jeśli są czasem między nami jakieś różne zdania [różnice zdań], to zawsze ktoś ustępuje, byle nie doprowadzać do rozbicia. My Poznaniacy najczęściej i najlepiej możemy

82 Tamże, List alumna Wacława K. do rektora Władysława Pawelczaka z dnia 3 września 1963 roku, s. 85-86.

${ }^{83}$ AASD, Korespondencja 1974-1979, s. 497-500. 
porozumieć się z kolegami z Gniezna. Tworzymy jakoby jedną rodzinę. Z nimi możemy zawsze się zrozumieć. $Z$ innymi seminariami nie zawsze jest dobrze ${ }^{84}$.

Jedność duchową i koleżeńską alumnów z Arcybiskupiego Seminarium Duchownego w Poznaniu potwierdzali też odwiedzający kompanie kleryckie koledzy z seminarium i profesorowie. Podczas wizyty w Bartoszycach w 1967 roku ks. prof. Jan Pytel zauważył: „Z radością stwierdziłem, że cała siódemka żyje w dobrej zgodzie, zachowuje dużą jednomyślność, wszelkie zagadnienia omawia wspólnie, jedynie w poszczególnych i nieprzewidzianych okolicznościach każdy decyduje sam i dzieli się swymi doświadczeniami z kolegami"85. Podobną opinię ksiądz prof. Jan Pytel sformułował po odwiedzinach alumnów w Brzegu i Szczecinie: „Jeśli chodzi o ocenę postawy alumnów poznańskich uważam, że jest ona dobra. Alumni nasi schodzą się na wspólne odmawianie różańca, pragną kontaktów z ojcem duchownym, starają się o wzajemną zgodę" ${ }^{\text {" }}$.

$* * *$

Zaangażowanie wojska w akcję niszczenia Kościoła katolickiego w Polsce przyniosło ograniczone efekty komunistycznym pomysłodawcom „eksperymentu kleryckiego". Wprawdzie w wyniku wywieranej presji udało się doprowadzić do zarzucenia drogi kapłaństwa przez pewną część kleryków-żołnierzy, ale zdecydowana większość alumnów będących ofiarami represyjnej polityki władz komunistycznych pozostała wierna powołaniu, przyjmując święcenia kapłańskie i poświęcając się pracy duszpasterskiej. Wielu z nich właśnie ten „eksperyment klerycki” umocnił w powołaniu, być może w jakimś też stopniu wzbogacając doświadczenia życiowe i duszpasterskie przyszłego kapłana.

Poddanie kleryków ścisłym rygorom wojskowym nie spowodowało załamania się w nich wiary ani zaufania do przełożonych. Próba obrzydzania Kościoła przez partyjnych i wojskowych propagandystów, chociażby w kontekście budzących duże emocje listu biskupów polskich do niemieckich braci w wierze z 1965 roku, również zakończyła się niepowodzeniem.

Najwyraźniej także władze komunistyczne świadome były porażki. Jeszcze na przełomie lat 1964/1965 poszukiwano w ramach „eksperymentu kleryckiego" nowych metod oddziaływania na kleryków (kierowanie alumnów

${ }^{84}$ AASD, Korespondencja 1966-1968, List alumnów D., Ch., D., K. do rektora ks. Władysława Pawelczaka z 4 stycznia 1966 roku, s. 222-223.

${ }^{85}$ Tamże, Sprawozdanie ks. Jana Pytla z wizyty w Bartoszycach, 27 listopada 1967 roku, s. 361.

${ }^{86}$ Tamże, Sprawozdanie ks. Jana Pytla z przebiegu składania przysięgi wojskowej w Szczecinie i Brzegu, 16 grudnia 1967 roku, s. 379-380. 
do specjalistycznych jednostek, skierowanie do nich lepiej przygotowanych kadr politycznych i dowódczych, zróżnicowanie metod pracy z klerykami), ale i one okazały się nieskuteczne. Po 1972 roku ,eksperyment klerycki” znalazł się w fazie schyłkowej, ale władze nie miały pomysłu, jak wycofać się z niego z zachowaniem twarzy. „Eksperyment” wprawdzie kontynuowano, ale bez przekonania, jakie charakteryzowało jego realizatorów na początku, i na skalę dużo mniejszą niż przed 1972 rokiem.

\author{
CONSCRIPTION OF CLERICS TO THE ARMY AS A FORM \\ OF REPRESSION OF THE COMMUNIST AUTHORITIES \\ AGAINST THE CATHOLIC CHURCH. \\ ALUMNI-SOLDIERS OF THE ARCHDIOCESE OF POZNAŃ
}

\title{
Summary
}

For the first time, clerics were conscripted for service in the People's Polish Army in 1955. It was a new method of repression applied to the Catholic Church, and its aim was to discourage candidates for priesthood to pursue their chosen way of life. The ending of this persecution was laid only by the election of the Polish Pope to the Holy See. In total, in the years 1955-1979 2,713 clerics were repressed throughout Poland.

The article discusses the historical background, motivations of the communist authorities, counteraction on the part of the Polish Episcopate and individual hierarchs, emphasizing in particular the protective actions taken by the clergy of the Poznan Archdiocese towards the clerical youth serving in the People's Polish Army. The source basis was the correspondence of seminarians with the superiors of the seminar and studies on the recent history of the state and the Church.

Słowa kluczowe: Arcybiskupie Seminarium Duchowne w Poznaniu, archidiecezja poznańska, Ludowe Wojsko Polskie, klerycy w wojsku

Keywords: Archbishop's Seminary in Poznań, Poznań Archdiocese, People's Polish Army, clerics in the army

\section{Bibliografia}

\section{Źródła archiwalne}

Archiwum Arcybiskupiego Seminarium Duchownego w Poznaniu

Korespondencja z alumnami w wojsku 1962-1965. 
Korespondencja z alumnami w wojsku 1966-1968.

Korespondencja z alumnami w wojsku 1974-1979.

\section{Literatura}

Albert A., Najnowsza historia Polski 1914-1993, t. 2, Warszawa 1995.

Banaszak M., Historia Kościoła katolickiego. Czasy najnowsze 1914-1978, t. IV, Warszawa 1992.

Chmielowiec P., Niewygodny ordynariusz. Rzeszowska Slużba Bezpieczeństwa wobec ordynariusza przemyskiego biskupa Ignacego Tokarczuka, [w:] Kościót w godzinie próby 1945-1989. Nieznane dokumenty i świadectwa, red. T. Balon-Mroczka, J. Szarek, Kraków 2006.

Cząstka A., Alkohol jako czynnik rozktadowy w rodzinie, „Wiadomości Duszpasterskie” 1950, nr 4/5.

Czubiński A., Historia Polski XX wieku, Poznań 2000.

Dudek A., Państwo i Kościól w Polsce 1945-1970, Kraków 1995.

Dudek A., Pytel G., Bolesław Piasecki. Próba biografii politycznej, Londyn 1990.

Dymek W., Tydzień Trzeźwości, „Miesięcznik Kościelny Archidiecezji Poznańskiej” 1948, nr 3, s. 81-83.

Dziurok A., Gomułkowska stabilizacja, [w:] Od niepodległości do niepodległości. Historia Polski 1918-1989, Warszawa 2014.

Friszke A., PRL wobec Kościoła. Akta 1970-1978, Warszawa 2010.

Gołdyn P., Klika Baziaka i Jatbrzykowskiego. Biskupi powiazani z diecezja lwowska i wileńska w oczach bezpieki, [w:] Kościót w godzinie próby 1945-1989. Nieznane dokumenty $i$ świadectwa, red. T. Balon-Mroczka, J. Szarek, Kraków 2006.

Jarosz D., Polacy a stalinizm, Warszawa 2000.

Kędzierski Ł., Działalność duszpasterska arcybiskupa Walentego Dymka (1939-1956), [w:] Ksiąz arcybiskup Walenty Dymek metropolita poznański (1888-1956), red. L. Wilczyński, Poznań 2010.

Kłoczowski J., Dzieje chrześcijaństwa polskiego, Lublin 2007.

Kłoczowski J., Müller L., Skarbek J., Zarys dziejów Kościoła katolickiego w Polsce, Kraków 1986.

Krawczak T., Ingerencja władz partyjno-rzadowych $w$ formowanie struktur kapłańskich - pobór kleryków do wojska, [w:] Kompanie kleryckie w Wojsku Polskim 1959-1980. Materiaty z konferencji naukowej zorganizowanej w 5 Pułku Inżynieryjnym w Szczecinie-Podjuchach, 8-9 września 2008, red. J. Kornak, Szczecin 2009.

Krukowski J., Represyjność prawa polskiego w zastosowaniu do Kościoła katolickiego w latach 1944-1956, [w:] Aparat ucisku na Lubelszczyźnie w latach 1944-1956 wobec duchowieństwa katolickiego, red. Z. Zieliński, Lublin 2000.

Kumor B., Historia Kościoła. Czasy wspótczesne 1914-1992, t. VIII, Lublin 2001.

Lasota M., Czasy PRL-u i odzyskana wolność 1945-1992, [w:] Dzieje Kościoła w Polsce, red. A. Wiencek, Bielsko-Biała 2008.

Lasota M., Ulice nie dla wiernych. Procesje pod nadzorem, [w:] Kościót w godzinie próby 1945-1989. Nieznane dokumenty i świadectwa, red. T. Balon-Mroczka, J. Szarek, Kraków 2006.

Lesiński A., Rola kadry wojskowej wobec alumnów-żotnierzy w świetle „Wytycznych generała Wojciecha Jaruzelskiego", [w:] Kompanie kleryckie w Wojsku Polskim 1959-1980. Materiaty z konferencji naukowej zorganizowanej w 5 Pułku Inżynieryjnym w Szczecinie-Podjuchach, 8-9 września 2008, red. J. Kornak, Szczecin 2009.

Listy pasterskie Episkopatu Polski 1945-1975, Paryż 1975.

Macholak J., Problemy szkolenia wojskowego żolnierzy-alumnów w raportach dowódców do spraw politycznych w latach 1959-1980, [w:] Kompanie kleryckie w Wojsku Polskim 1959-1980. Materiaty z konferencji naukowej zorganizowanej w 5 Pulku Inżynieryjnym w Szczecinie-Podjuchach, 8-9 września 2008, red. J. Kornak, Szczecin 2009.

Metody pracy operacyjnej aparatu bezpieczeństwa wobec Kościolów i związów wyznaniowych 1945-1989, red. A. Dziurok, Warszawa 2004. 
Mędlewski N., Śp. Ksiądz Arcybiskup Walenty Dymek Metropolita Poznański, „Miesięcznik Kościelny Archidiecezji Poznańskiej” 1957, nr 1/2.

Musiał F., Śmierć po wyroku. Ksiądz Józef Fudali prześladowany przez UB, [w:] Kościół w godzinie próby 1945-1989. Nieznane dokumenty i świadectwa, red. T. Balon-Mroczka, J. Szarek, Kraków 2006.

Okólnik nr 5 Poznańskiej Kurii Metropolitalnej w 1950 roku, 25 września 1950 roku, [w:] Okólniki Kurii Metropolitalnej w Poznaniu 1949-1953.

Pawlicka K., Polityka władz wobec Kościoła katolickiego (grudzień 1970 - październik 1978), Warszawa 2004.

Protokół z plenarnego posiedzenia KC PPR 10 lutego 1946 roku, „Archiwum Ruchu Robotniczego", t. IX, Warszawa 1984.

Raina P., Kościót w PRL. Kościól katolicki a państwo w świetle dokumentów 1945-1989, t. I (lata 1945-1959), Poznań 1994.

Setlak A., Slużba wojskowa alumnów Wyższych Seminariów Duchownych w PRL i jej ocena w wypowiedziach alumnów i kapłanów rezerwistów. Studium historyczno-socjologiczne na przykladzie Bartoszyc, Olsztyn 2002.

Stopniak F., Kościół na ziemiach polskich w latach 1848-1978, [w:] Historia Kościoła od 1848 roku do wspótczesności, t. V, red. R. Aubert, Warszawa 1985.

Szarek J., Bezpieka na dróżkach. Kalwaria Zebrzydowska, [w:] Kościót w godzinie próby 1945-1989. Nieznane dokumenty i świadectwa, red. T. Balon-Mroczka, J. Szarek, Kraków 2006.

Szarek J., Osaczony kapelan. Agentura wokót księdza Władysława Gurgacza, [w:] Kościót w godzinie próby 1945-1989. Nieznane dokumenty i świadectwa, red. T. Balon-Mroczka, J. Szarek, Kraków 2006.

Terlecki R., Wielki wygnaniec. Metropolita krakowski ksiadz arcybiskup Eugeniusz Baziak, [w:] Kościól w godzinie próby 1945-1989. Nieznane dokumenty i świadectwa, red. T. Balon-Mroczka, J. Szarek, Kraków 2006.

Walusiak D., TEOK. Teczka Ewidencji Operacyjnej na Księdza, [w:] Kościół w godzinie próby 1945-1989. Nieznane dokumenty i świadectwa, red. T. Balon-Mroczka, J. Szarek, Kraków 2006.

Weiss A., Banaszak R., Niższe Seminarium Duchowne Archidiecezji Poznańskiej (1949-1960), Poznań 1999.

Werth N., Przemoc przeciwko społeczeństwu. Przemoc, represje i terror w Zwiazku Sowieckim, [w:] Czarna księga komunizmu, thum. K. Wakar i in., Warszawa 2001.

Wielkie dzieło, „Miesięcznik Kościelny Archidiecezji Poznańskiej”, nr 10 (1947).

Wilczyński L., Ksiadz Arcybiskup Walenty Dymek. Efekty inwigilacji, [w:] Ksiadz arcybiskup Walenty Dymek metropolita poznański (1888-1956), red. L. Wilczyński, Poznań 2010.

Wojcieszyk E., Wojewódzki Urząd Bezpieczeństwa Publicznego w Poznaniu wobec Caritas Academica w latach 1946-1950, [w:] Zmagania ze spoleczeństwem. Aparat bezpieczeństwa wobec Wielkopolan w latach 1945-1956, red. A. Łuczak, A. Pietrowicz, Poznań 2008.

Wojtkowiak S., Dobra martwej ręki w dawnej Polsce i dziś, „Res Humana”, nr 2-3, 2005.

Wyszyński S., Dzieła zebrane 1949-1953, t. I, Warszawa 1991.

Zamiatała D., Caritas. Działalność i likwidacja organizacji 1945-1950, Lublin 2000.

Zawadzki J., Zagadnienie trzeźwości w Piśmie Świętym, „Wiadomości Duszpasterskie” 1950, nr 8.

Zieliński Z., Kościół w Polsce 1944-2007, Poznań 2009.

Żaryn J., Kościót katolicki w PRL - wybrane zagadnienia, hipotezy, prowokacje, „Pamięć i Sprawiedliwość", nr 1/2005.

Żaryn J., Kościót w Polsce w latach przełomu (1953-1958), Warszawa 2000.

Żaryn J., Ostatnie wygnanie biskupa Stanisława Adamskiego (1952-1956), „Więź”, nr 4, 1998.

Żurek J., Aparat bezpieczeństwa wobec Kościoła katolickiego w Polsce. Wybrane struktury (1944-1953), „Aparat Represji w Polsce Ludowej 1944-1989”, 1/3/2006.

Żurek J., Ruch „,księży patriotów” w województwie katowickim w latach 1949-1956, Warszawa-Katowice 2009. 